\title{
Environmental Radiological studies Conducted During 1986 in the Vicinity of the Rancho Seco Nuclear Power Generating Station
}

V.E. Noshikin

K.M. hong

R.J. Eagle

J.L. Brunk

T.A. Jokela

\section{DISCLAIMER}

\begin{abstract}
This repost was prepijed ats an account of work sponsored by an agency of the Uniled Stales Government. Neither the Uniled States Govelnment no: any ageney theseof. nor any of their employees, makes any warranty, express or implied, or assumes any tegal liability or eresponsibitily for the accuracy, completeness, or usefulness of any information, apparatus, product, or process disclosed, or represents that its use would not infringe privately owned righis. Reference herein la any specific commercial product, fiocest, or scrvice by trade name, traderiark. manufacturer, or otherwise does not necessarily constitute or imply its endorsemen, recommendation, or lavoring by the United States Government or any agency thereof. The views and opinions of authors expressed herein of nor necessarily state or sellect thase of the United States Government or any agency therebf.
\end{abstract}

\section{MASTER}

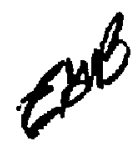




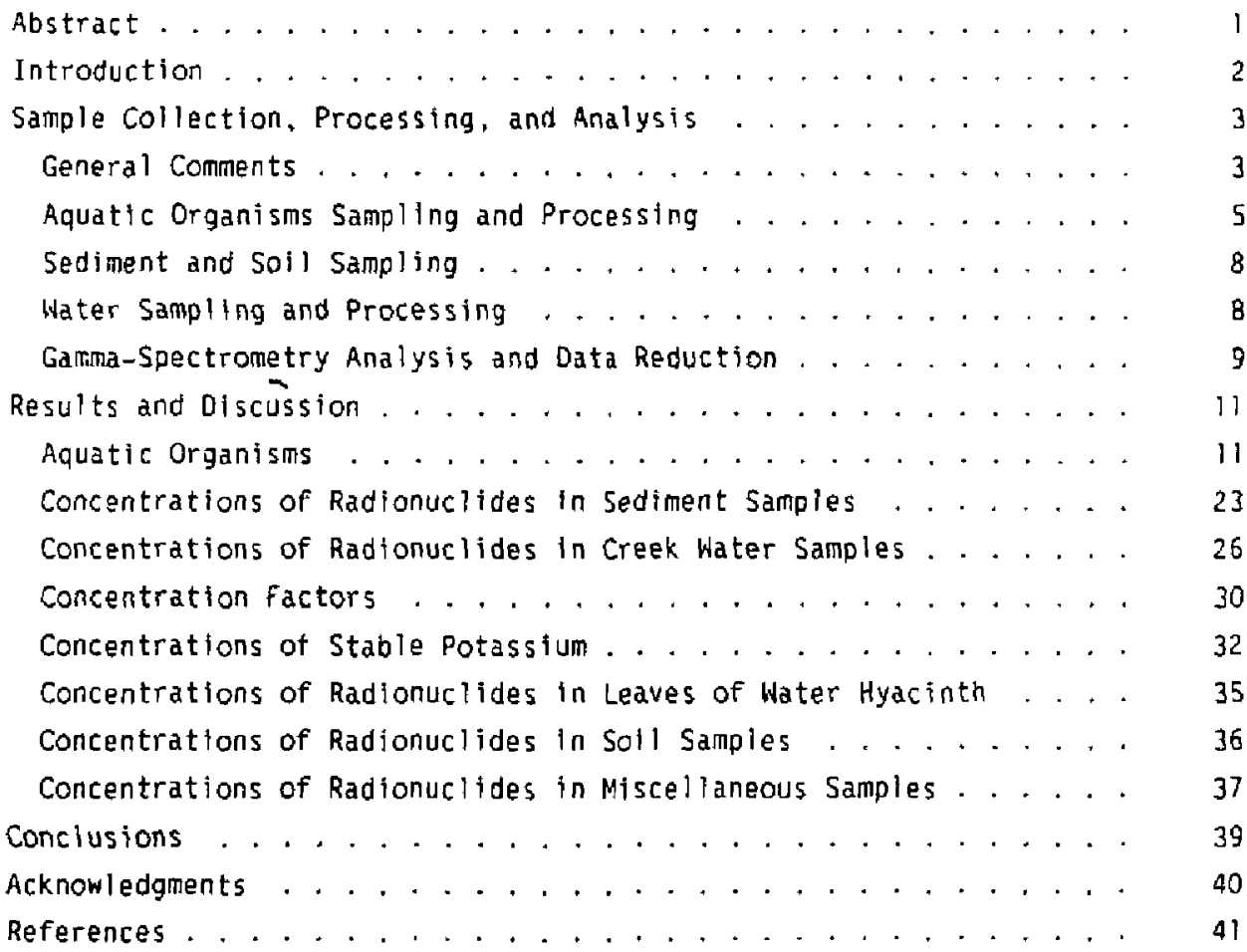


Appendix I Concentrations of Radionuclides in Fish . . . . . . . . . I

Appendix II Concentrations of Radionucilides in Frog Legs . . . . . . . 16

Appendix III Concentrations of Radionuclides in Crayfish . . . . . . . 18

Appendix IV Concentrations of Radionuclides in water Samples... . . 20

Creek Water Samples Collected in 1986........ . 21

Miscellaneous Water Samples Collected in 1986.... . 23

Appendix $V \quad$ Concentrations of Stable Potassium in Water Samples . . . 24

Afpendix VI Concentrations of Radionuclides in Water Hyacinth . . , , 26

Appendix VII Concentrations of Radionuclides in Sediments . . . . . . . 29

12-cm Deep Creek Sedlments ............. 30

Core from Station R-5. . . . . . . . . . . . . . . . 33

Appendix VIII Concentrations of Radianuclides in Soil Samples . . . . . 34

Gudgel Ranch Samples of Soil and Grass . . . . . . . . 35

Surface Solls $11 \mathrm{~km}$ from Rancho Seco . . . . . . . . . 36

Miscellaneous Soit Samples. . . . . . . . . . . . . . 37

Soil-Profile Samples at RSP 1 and RSP 5 . . . . . . 38

Appendix Ix Concentrations of Radionuclides in Sone Other

Terrestrial Samples. . . . . . . . . . . . . . 39 
Thts report sumarizes the information compiled in 1985 for our assessment of the environmental impact of radionuclides discharged with aqueous releases from the Rancho Seco Nuclear Power Generating Plant. In October 1984, a liquid-effluent control program was initiated that significantly reduced the quantities of radionuclides discharged with liquid waste from the plant. However, results from our sampling program in 1986 indicate that previously discharged radionuclides persist in the downstream environment and are found in many aquatic dietary components although at concentrations much lower than those measured in 1984 and 1985 . The greatly reduced activities in the dietary components from the aquatic environment attest to the effectiveness of the liquid-effluent control program. Concentrations in the flesh of fish from the creeks have decreased over time and with distance from the plant outfall. These changes in concentrations can be described by exponential equations, the coefficients of which are obtained from a least-squares analysis of the data. The mean concentration of ${ }^{137} \mathrm{Cs}$ in fish collected from Laguna Creek at locations more than $7.5 \mathrm{~km}$ from Rancho Seco is now comparable to the concentration determined in fresh-water fish randomly seiected from Chicago, Illinois, markets. By August 1986, the mean concentration of ${ }^{137} \mathrm{Cs}$ in the flesh of bluegill had fallen to $7 \%$ of the concentration measured in fish from comparable locations in 1984 and was $30 \%$ of the mean concentration measured in these fish during August 1985 . 5table potasstum in the water plays a major role in the accumulation of ${ }^{137} \mathrm{Cs}$ by fish. Concentrations of ${ }^{137} \mathrm{Cs}$ in the surface sections of creek sediments also declined between the end of 1984 and 1986 with an effectfve ha?f-iife of approximately $2 \mathrm{y}$. Surface solls collected around a perimeter $11 \mathrm{~km}$ from Rancho Seco and from ranchlands closer to the plant showed only concentrations of $137 \mathrm{Cs}$ originating from global fallout. Solls previously irrigated with Clay Creek water retain leveis of both $134 \mathrm{Cs}$ and $137 \mathrm{Cs}$. 
INTRODUCTION

The Rancho Seco Nuclear Power Generating Station, operated by the Sacramento Municipal Utility Distric: (SMUD), is located in Sacramento County near the town of Clay, California.

Steam-generator leaks, which occurred at the plant in May 1981, November 1982, September 1983, and July 1984, contributed low-level quantities of some fission and activation products to plant wastewaters. These wastewaters were collected in holding tanks located on the site. The type and quantity of radionuclides in the liquid waste contalned in each holdup tank vere determined by SMUD prior to release of the material to on-site retention basins.

Periodically the contents of the basins, or fractions of the contents, were diluted and discharged to Clay creek. The water in this creek flows to the site boundary fence, $0.5 \mathrm{~km}$ fron the point of discharge, and continues until it intersects Hadselville Creek, $3.0 \mathrm{~km}$ downstream from the plant. Water from Hadselville Creek intersects Laguna Creek $6.5 \mathrm{~km}$ downstream from the plant. Laguna Creek water drains into the Cosumnes River at a point near Twin Cities Road between Interstate Highway 5 and State Highway 99.

In October 1984, a liquid-effluent control program was initiated by the Distrlct; it has significantly reduced the quantities of radionuclides discharged with liquid wastes from the plant. Releases of ${ }^{137} \mathrm{Cs}$ and ${ }^{134} \mathrm{Cs}$ (the two radionuclides contributing the major fraction of the estimated dose to individuals) decreased from 1984 measured values of $300 \mathrm{mCl}$ and $150 \mathrm{mCl}$. respectively, to $4 \mathrm{mCl}$ and $2.5 \mathrm{mCi}$ in 1985 , and to less than $1 \mathrm{mCl}$ total $137 \mathrm{Cs}$ and $134 \mathrm{Cs}$ during the first half of 1986 ( 1 ).

In the spring of 1984, we initiated a scientific program to obtain site-specific analytical Information about the concentrations and fate of the gamma-emitting radionuclides discharged with liquld wastes from Rancho Seco. A major priority for off-site dose assessments was to determine the levels of radionuclides, in particular ${ }^{134} \mathrm{Cs}$ and $137 \mathrm{Cs}$, associated with the edible parts of organisms in the aquatic food pathway to man.

As the study progressed, we were requested to expand the program to provide a variety of other radjological information that could be used by SMUD to estimate doses from other pathways to provide rrasonable assurance to the 
local population, governmental agencies, and other interested parties that no individual will receive an annual dose to the whole body from previously discharged radloactivi:y that exceeds the EPA guideline of $25 \mathrm{mrem}$.

The results from the scientific studies conducted during 1984 and 1985 are summarized in previously pubitshed reports $(2,3,4,5,6,7)$.

No previous studies adequately address the contamination of food products or the biological availability of radiocesium when components in stream-bed sediments, rather than stream water, are the source of radionuclides. Because radionuclides associate with sediments, there is a sedimentary source term in the aquatic environment downstream from Rancho Seco. Consequentiy, one major objective in 1986 was to determine the rate at which the ${ }^{137} \mathrm{Cs}$ and ${ }^{134} \mathrm{Cs}$ concentrations change in fish and other organisms; this determination will? permit reasonable estimates of radiological dose from the consumption of any aquatic food product to continue to be made.

Additional downstream sampling stations were added in 1985 and 1986 to better define relationships between differences in concentrations in fish cand other environmental samples) with time and downstream distance. The analytical results generated from the environmental samples collected during 1986 are presented in this report. Some of the studies are continuations of efforts initiated in 1984, while others developed from recommendations (5,6) made after an assessment of our results from the first two years of effort.

SAMPLE COLLECTION, PROCESSING, AND ANALYSIS

\section{Genera 1 Comments}

Table I shows a comparison of the types and number of samples collected for analysis during 1984, 1985 and 1986. The total number of samples collected in 1986 for processing and analysis represents a $77 \%$ increase over the number collerted in 1985 and a $170 \%$ increase over the number of samples collected in 1984. This increased effort in 1986 was necessary for several reasons. Four additional fish collection sites were added to the program to provide additional data that would fill the information gaps noted in our 1985 data base. We also made an increased effort to collect and analyze frogs, erayfish, and water hyacinth from downstream locations. A further reason we 
Table 1. Types of environmental samples collected and anaTyzed for gammaemitting radionuclides in 1986 compared to those collected in 1985 and 1984 .

\begin{tabular}{|c|c|c|c|}
\hline Sample type & $\begin{array}{l}\text { No. of sampies } \\
\text { collected } 1986\end{array}$ & $\begin{array}{l}\text { No, of samples } \\
\text { collected } 1985\end{array}$ & $\begin{array}{l}\text { No. of samples } \\
\text { collacted } 1984\end{array}$ \\
\hline \multicolumn{4}{|l|}{ Fish } \\
\hline Bluegill & 638 & 375 & 190 \\
\hline Bass & 206 & 144 & 114 \\
\hline Catfish & 155 & 182 & 23 \\
\hline other & 6 & 0 & 8 \\
\hline \multicolumn{4}{|c|}{ Other aquatic samples } \\
\hline Frog & 169 & 88 & 0 \\
\hline Crayfish & 159 & 48 & 2 \\
\hline hater hyacinth & 39 & 10 & 0 \\
\hline Stream sediment & 90 & 53 & 224 \\
\hline \multicolumn{4}{|l|}{ Stream water for } \\
\hline radionuclides & 42 & 46 & 18 \\
\hline \multicolumn{4}{|l|}{ Stream water for } \\
\hline jtable $k$ & 35 & 4 & 0 \\
\hline Duck & $\dot{v}$ & $0^{\prime}$ & 4 \\
\hline \multicolumn{4}{|l|}{ Terrestrial samples } \\
\hline Cattle & 1 & 5 & 1 \\
\hline Pasture grass & 8 & 2 & 5 \\
\hline Sflage & 3 & $i$ & 2 \\
\hline Sol1 & 38 & 12 & 10 \\
\hline Well water & 2 & 20 & 0 \\
\hline Honey & 2 & $\mathbf{i}$ & 1 \\
\hline Blackberries & 3 & 0 & 2 \\
\hline $1411 \mathrm{k}$ & 0 & 0 & 2 \\
\hline $\operatorname{corn}$ & 0 & 0 & 2 \\
\hline TOTAL & 1634 & 987 & 608 \\
\hline
\end{tabular}


increased the number of samples was a direct result of the lower concentrations now found in fish and other organisms: lower concentrations require a larger sample size for rellable analysis.

Locations of the sampling stations referred to in this and past reports are shown in Fig. 1. In August, we were asked to sample soil and grass from the ranch of Mr. R. Gudgel. The location of the ranch is shown in Fig. 1 . Figure 2 is an enlarged plot of the sections of the ranchland showing the locations sampled. Data for the soll and grass from the different ranch sections are provided in Appendix VIII, Detailed discussions of the collection methods, sample processing, and analysis can be found in previously published reports $(3,4,5,6)$. Abbreviated yersions of these discussions follow.

\section{Aquatic Organism Sampling and Processing}

Fish collections were made using flshing gear with either bait or artificial lures. This method was adopted over other authorized fishing methods, or methods such as chemical immobilization or electric shock, because it best mimicked the method used by local fishermen. Thus, the fish sampled would be more representative of the species normally caught from the creeks for consumption. A total of 1005 fish were collected for analyses from 12 downstream locations in 1986. Of this total, there were 638 bluegill, 206 bass, and 155 catfish. The land-and aquatic-use survey (2) indicated that bluegill, bass, and catfish were the species normally caught for consumption by the local residents. This fact justified the choice of the fish sampled for analysis.

Crayfish were captured in commercial traps using cat food for bait. Frogs wele speared at night from downstream locations on the creeks. We are indebtoj to Mr. Roy Marciel of the staff at Rancho Seco for assisting with the frog collectlons.

Samples were kept on ice and returned to Lawrence Livemore National Laboratory (LLNL), where the organisins were frozen until processed. The standard length, sex, and fresh whole-body weight of each fish were recorded, and the flsh were dissected to separate the edible flesh for analysis. The flesh from fish of the same species that were collected from the same sampling site were sometimes pooled for analysis. The judgment to analyze single or pooled samples of fish was based on anticipated concentrations at the sampling 
Figure 1. Location of sampling stations. 


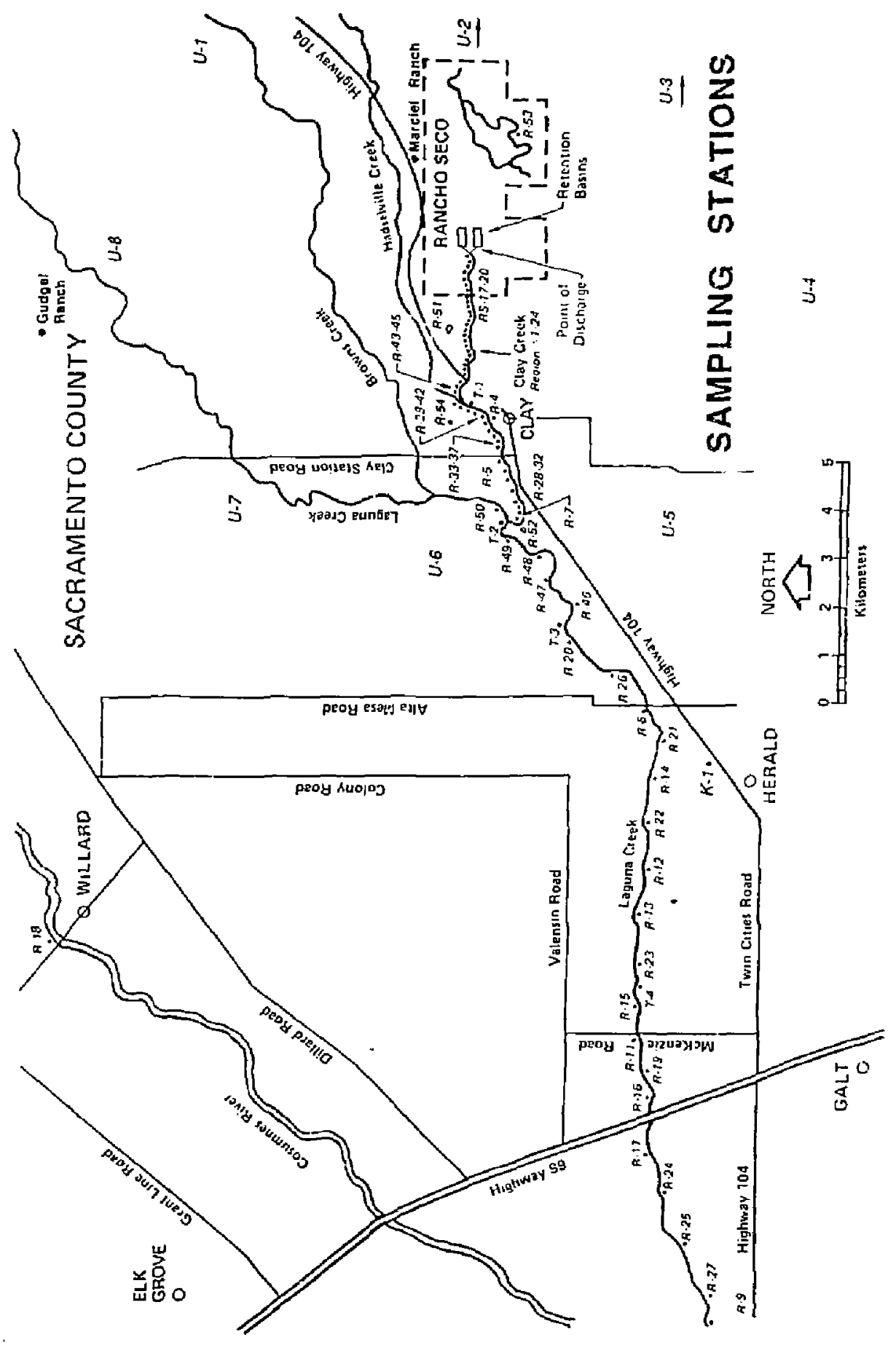


Figure 2. Location of plots sampled at the Gudgel Ranch. 


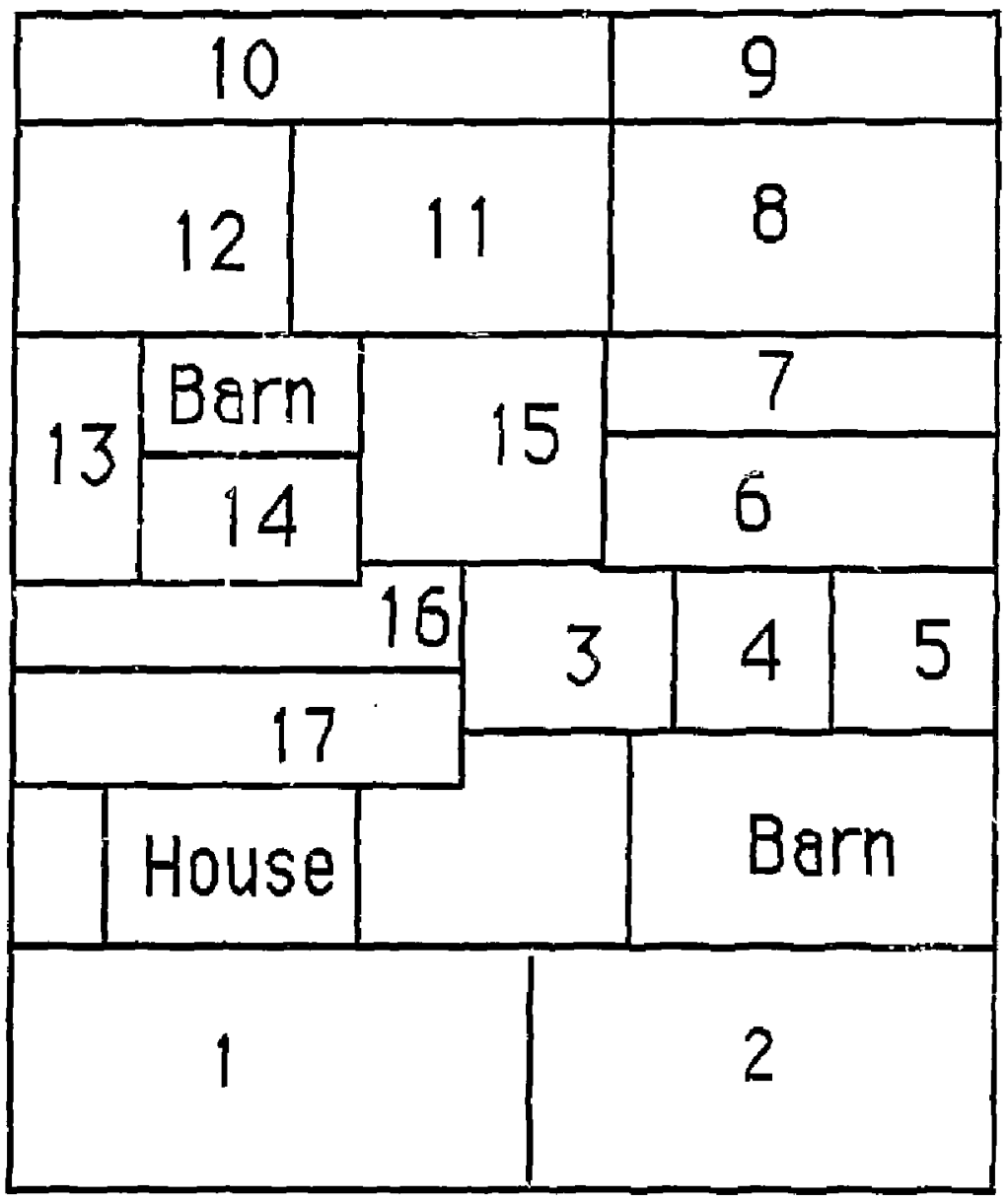


sites. Frog legs were separated from the body, skinned, and deboned to provide samples of edible flesh; the flesh from small frogs was often pooled for analysis. The edible portion of the crayfish was separated from several individuals and pooled for analysis. Each sample was dried in an oven at $90^{\circ} \mathrm{C}$ to constant weight, homogenized, and transferred to aluminum or plastic containers for analysis by gamma spectrometry. Material with low levels of activity was often ashed to produce a more condensed sample having a better geometry for counting by gamma spectrometry.

Sampling and processing the terrestrial aninal and vegetation samples have been previously described (5).

\section{Sediment and Soil sampling}

The same devices used to collect sediment and soit samples in 1984 and 1985 were used to obtain samples in 1986. Sediment to a depth of $12 \mathrm{~cm}$ was collected from the creeks using a stainless steel hand corer; the entire 12-cm section was dried, sieved (to remove large rocks), ball-milied, and analyzed as a single sample.

\section{Water Sampling and Processing}

Fifty-liter water samples were usually obtained at stations in conjunction with the fish collections. The water was pumped through $1-\mu m$ ipore size) cartridge filters into 15-gal polyethylene containers, acidifed and returned to LLNL for processing. Cestum isotopes were first concentrated on ammonium moiybdophosphate (AMP); the AlAP was separated from the water by filtration; and the cesium was then separated from the AMP and prepared as solid samples for analysis on $G(L I)$ detectors. The $1-\mu m$ filters containing the particulate material were ashed at $450^{\circ} \mathrm{C}$, and concentrations of radionuclides in the particulate material were determined by gamma spectrometry.

Unfiltered ground water was sampled for analysis from domestic fresh-water wells located in the vicinity of Rancho Seco. Fifty-liter samples were obtained at each of the locations. described above for ${ }^{134} \mathrm{Cs}$ and $137 \mathrm{Cs}$. Trittum measurements were made on al lquots from the same samples. 
Gamma-spectrometry measurements were made on all samples at LLHL using a variety of Ge(Li)-diode detector systems. Counting times were usually $1000 \mathrm{~min}$ or longer for each sample. A general purpose computer program, called GAMANAL ( 8 ), was used for the data reduction of all gamma-ray spectra. In GAMANAL, the observed photopeak in the measured spectra is compared to that in a library of photopeaks of gamma-ray fission and activation products and naturally occurring radionuclides to identify the radionuclides in the sample. All radionuclides routinely released to the waterway from the plant are included in the library. The program then applies correction factors for sample s1ze, density, counting time, counting geometry, and decay to convert the measured counting rate to $\mathrm{pCl} / \mathrm{g}$ of sample on the reference date sampled. The program also generates an upper-limit amount of specific radionucijdes based on those spectral regions where signals would be seen if the radionuclide were present in detectable quantities. Our mean minimal detectable concentrations (based on a counting time of $1000 \mathrm{~min}$ ) for each of the principal longer-lived gamma-emitting radionuclides prevlously discharged to Clay Creek are shown in Table 2. These value are the averages for the different sample configurations (geometries) and are independent of sample weight. Samples prepared for analysis ranged in weight from a fraction of a gram for dry stomach contents of fish to over $300 \mathrm{~g}$ for dry soil. Detection limits on a per gram basis are, therefore, different for samples of different weights.

Data quality has always been an important aspect of our analytical measurements. As a standard practice, 5 to $10 \%$ of our time is devoted to quality-assurance work in all projects involving analytical measurements. This quality-assurance work includes:

- Analysis of background samples and blanks.

- Instrument calibration.

- Duplicate sampling and analysis.

- National and international interlaboratory standardization.

- Replicate measurements.

- Analysis and calloration traceable to National Bureau of Standards (NBS) samples.

- Appropriate statistical analysis of the results. 
Table 2. Mean detection limits of selected gamma-emitting radionuclides released in liquid effluents from Rancho Seco ( $\mathrm{pCi} / \mathrm{sample).a}$

Radlonuclide

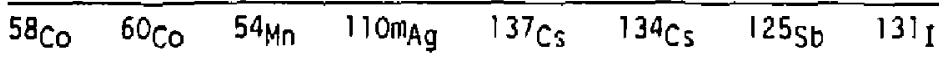

\begin{tabular}{|c|c|c|c|c|c|c|c|c|}
\hline $\begin{array}{l}\text { Detection } 1 \text { imit } \\
\text { (pCi/sample) }\end{array}$ & 1 & 1 & 1 & 1 & 1 & 1 & 3 & 2 \\
\hline
\end{tabular}

a Based on a counting time of $1000 \mathrm{~min}$; prior to decay correction. 


\section{RESULTS AND OISCUSSION}

All of the 1 ndividual sample results for 1986 appear in a separate volume of this report, UCID-20963 Part II (Appendices).

\section{Aquatic Organisms}

The concentrations of the radionucijdes measured in the muscle tissue of the fish from the different stations are given in Appendix I. All results have been decay corrected to the date of collection. The data in the Appendix are arranged to show concentrations in the samples of fish according to the time sampled and according to increasing distance downstream from Rancho Seco. The concentrations are listed relattve to fresh wet weight, but the dry/wet weight ratios provided may be applied to convert concentrations to a dry-weight basis. Other than $134 \mathrm{Cs}$ and $137 \mathrm{Cs}$, no gamma-emitting radionuclides from plant discharges were above detection limits in the flesh of the fish. Concentrations of natural $40_{K}$ in the flesh of fish are also provided in the tables.

The welghted mean concentration for both ${ }^{134} \mathrm{Cs}$ and ${ }^{137} \mathrm{Cs}$ in the fiesh of fish during the month collected is computed using Equation (1). First, the sum of the products of the concentration $\left(C_{j}\right)$, the number of $f i$ sh in the sample $\left(n_{1}\right)$, and the whole-body fresh welght $\left(w_{j}\right)$ is determined. This sum is divided by the sum of the products of the whole-body fresh weight and the number of fish in the respective sample.

$$
C(\mathrm{pCl} / g \text { wet })=\Sigma C_{1} w_{1} n_{1} / \Sigma w_{j} n_{j}
$$

Our sampling locaticrs were selected to enable us to examine the difference in the ${ }^{137} \mathrm{Cs}$ (and ${ }^{134} \mathrm{Cs}$ ) concentrations in flesh as a function of the distance downstream and as a function of time. Mean concentrations of ${ }^{137} \mathrm{Cs}$ and ${ }^{134} \mathrm{Cs}$ in the flesh of blueg111, bass, and catfish collected at downstream stations during 1984, 1985, and 7986 are shown in Tables 3 to 5 . Reading across these tables from left to right shows the change in the concentration of ${ }^{137} \mathrm{Cs}$ and ${ }^{134} \mathrm{Cs}$ in the flesh of fish with distance downstream 
from Rancho Seco. Reading the tables from top to botton shows the trend for the change in concentration at each sampling station with time.

Data from the preceding tables were used to construct figs. 3 to 7 , which show the change in concentration with time for $137 \mathrm{Cs}$ in the flesh of the bluegill, bass, and catfish caught at 5 downstream stations. The stations are located on the creeks between 0.5 and $12.6 \mathrm{~km}$ downstream from Rancho Seco. In general, the mean concentration in the fish from all downstream stations began to decrease in early 1985 a few months after the effluent control program was initiated at Rancho Seco.

Figure 8 shows the change over time since 1985 in the natural log of the ${ }^{134} \mathrm{Cs} /{ }^{137} \mathrm{Cs}$ activity ratio measured in fish from stations $\mathrm{RS}-17$ and $\mathrm{T}-1$ (shown plotted on days since January 1, 1984). The ${ }^{134} \mathrm{Cs}$ has been decreasing and now has an effective half life of $2.0 \mathrm{y}$; this is essentially the radiological half-1ife of ${ }^{134} \mathrm{Cs}(2.06 \mathrm{y})$. No new ${ }^{134} \mathrm{Cs}$ has been generated at the plant since the reactor was shut down for maintenance. In 1986, the mean activity ratio in aquatic samples was 0.25 .

Flgures 9 and 10 show tiin change in concentration of ${ }^{137} \mathrm{Cs}$ in the flesh of b]uegill collected downstream for 1985 and 1986. The regression lines in the figures result from a least-squares analysis of the concentrations measured at the downstream stations during the first and final sampling period of each year. By October 1986, the mean concentration in bluegill flesh decreased by half every $2.3 \mathrm{~km}$ downstream from the plant. Between March 1985 ind October 1986, the concentration decreased at each station, with a mean effective half-life of approximately $170 \mathrm{~d}$.

Changes in the mean concentration of $137 \mathrm{Cs}$ in the flesh of bass and catfish during 1985 and 1986 were not as uniform as the chariges noted in bluegill (Tables 3 to 5 ). For example, the mean concentrations of $137 \mathrm{Cs}$ and ${ }^{134} \mathrm{Cs}$ in bass caught at stations $T-1, R-5$, and $T-2$ during certain months in 1985 were higher than those in fish caught during preceding months (see Table 4). Figure II shows the concentrations measured in the flesh of bass caught at downstream stations during July 1985 and September 1986. Reasonably good correlations were found for the regression lines developed from the data. The concentrations in fish caught nearest the plant changed only sightly between the sampling dates, while more significant differences are noted between the average concentrations in fish from greater downstream distance. 
Table 3. Mean concentration of ${ }^{137} \mathrm{Cs}$ and ${ }^{134} \mathrm{Cs}$ in flesh of bluegill caught at different downstream stations from 1984 to 1986. (")di" means less than detection llaits.)

Station ID and downstream distance (km)

$\begin{array}{lcclllllllll}\text { Date } & \text { RS-17 } & \text { RS-30 } & \text { RS-15 } & \text { T-1 } & \text { R-5 } & \text { T-2 } & \text { T-3 } & R-8 & R-22 & T-4 & R-11 \\ \text { sampled } & 0.5 & 0.5 & 1.5 & 3.0 & 4.6 & 7.5 & 10.2 & 12.6 & 15.4 & 17.2 & 19.5\end{array}$

${ }^{137} \mathrm{Cs}(\mathrm{pCi} / \mathrm{g}$ wet $\mathrm{wt})$

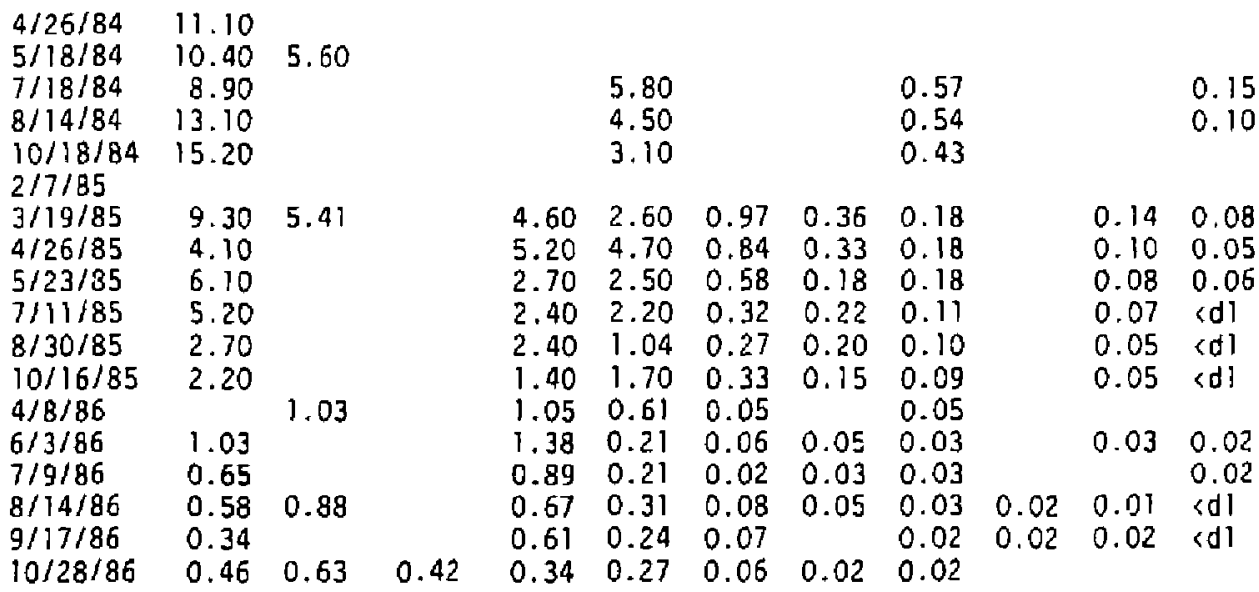

${ }^{134} \mathrm{Cs}$ ( $\mathrm{pCi} / \mathrm{g}$ wet $\left.w \mathrm{t}\right)$

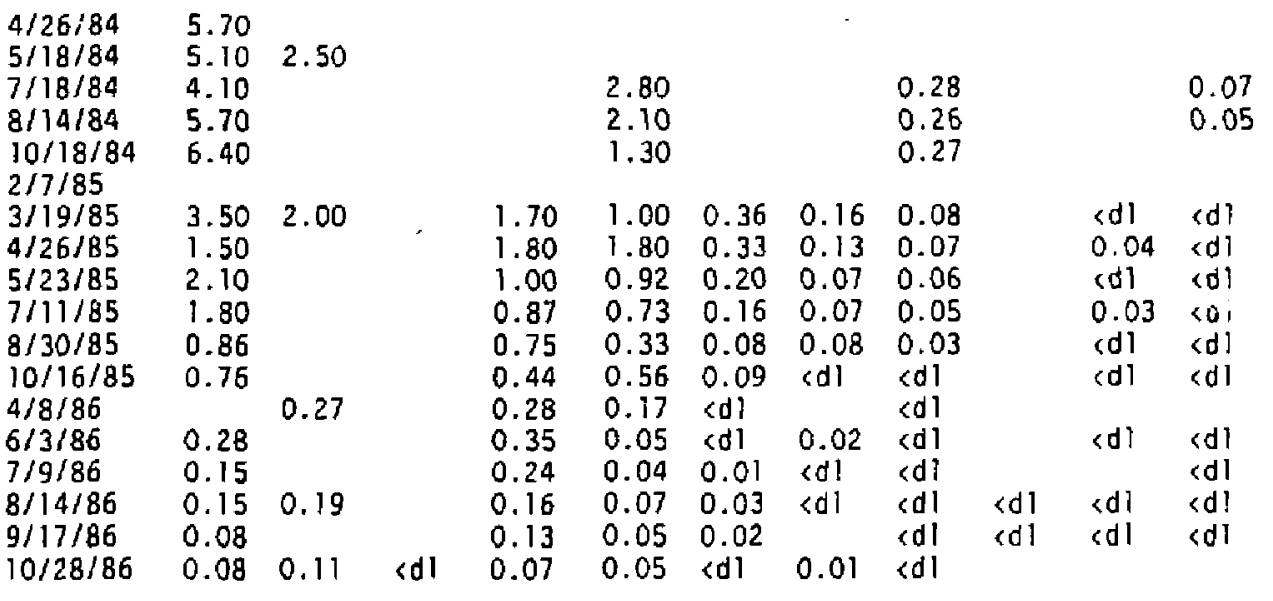


Table 4. Mean concentration of ${ }^{137} \mathrm{Cs}$ and ${ }^{134} \mathrm{Cs}$ in flesh of bass caught at different downstream stations from 1984 to 1986 . ("cdl" means less than detection 1 imits.)

Station 10 and downstream distance $(\mathrm{km})$

$\begin{array}{lccccccccccc}\text { Date } & \text { RS-17 } & \text { RS-30 } & T-1 & R-5 & R-7 & T-2 & T-3 & R-8 & R-22 & T-4 & R-11 \\ \text { sampled } & 0.5 & 0.5 & 3.0 & 4.6 & 6.3 & 7.5 & 10.2 & 12.6 & 15.4 & 17.2 & 19.5\end{array}$

${ }^{137} \mathrm{Cs}(\mathrm{pCj} / \mathrm{g}$ wet $w \mathrm{t})$

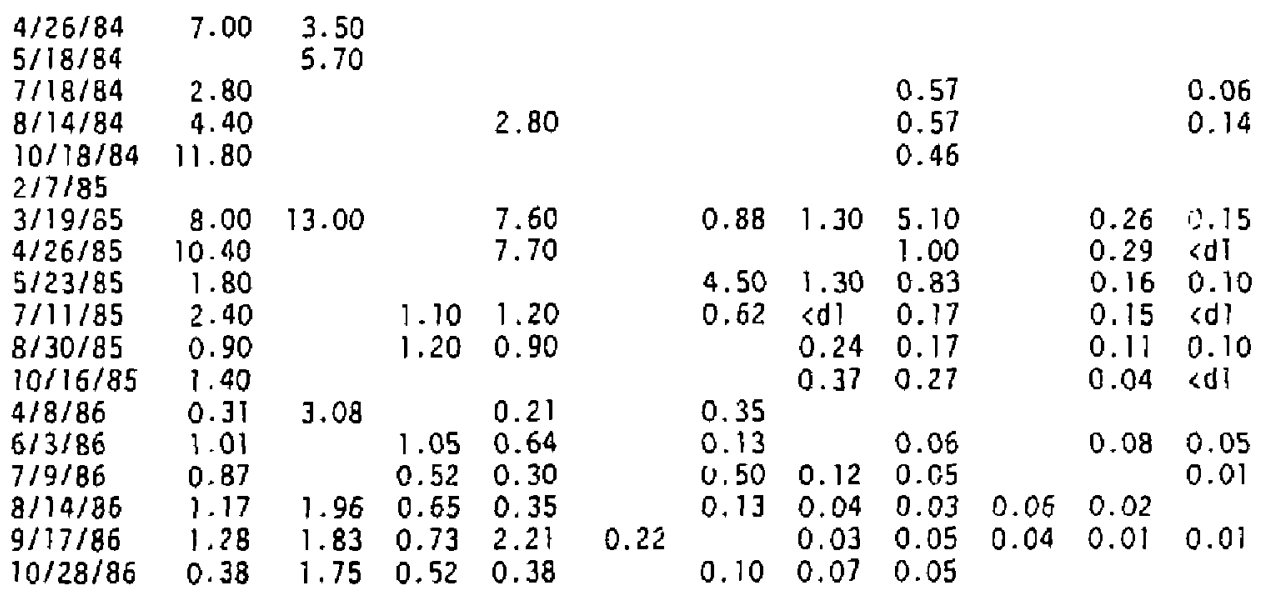

$134 \mathrm{Cs}$ (pCi/g wet wt)

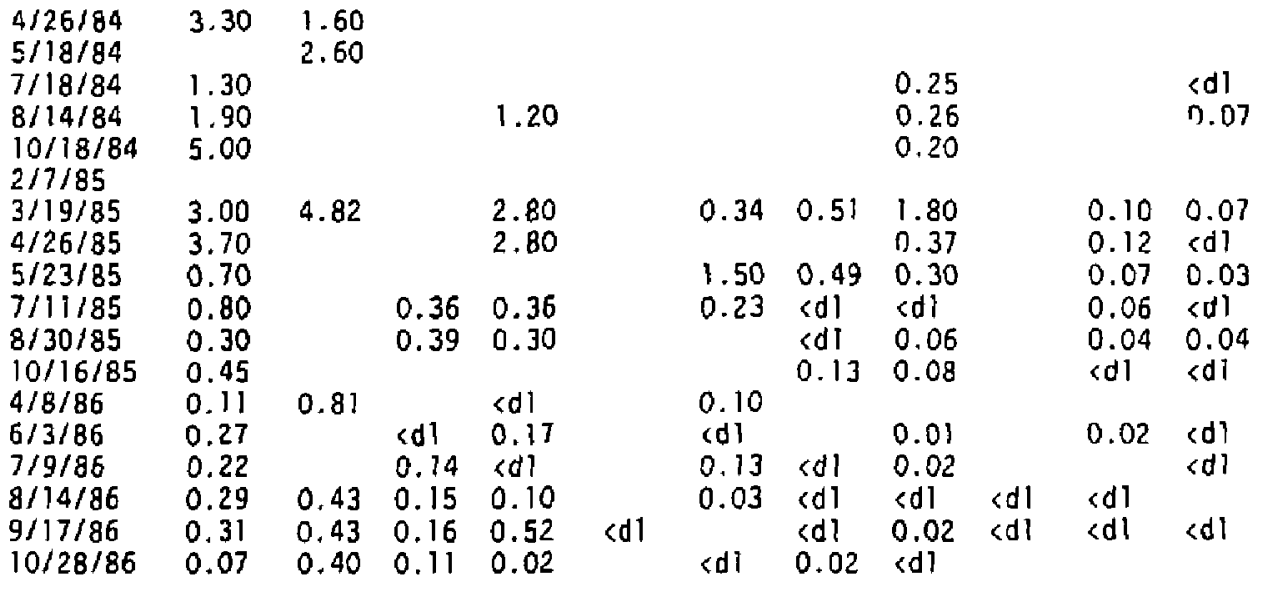


Table 5. Mean concentration of ${ }^{137} \mathrm{Cs}$ and ${ }^{134} \mathrm{Cs}$ in flesh of catfish caught at different downstream stations from 1984-1986. (" $<d 1 "$ means less than detection limits.)

Station ID and downstream distance (km)

$\begin{array}{lccccccccccc}\text { Date } & \text { RS-17 } & \text { RS-30 } & T-1 & R-5 & \text { RS-52 } & \text { T-2 } & T-3 & R-8 & R-22 & T-4 & R-11 \\ \text { sampled } & 0.5 & 0.5 & 3.0 & 4.6 & 6.0 & 7.5 & 10.2 & 12.6 & 15.4 & 17.2 & 19.5\end{array}$

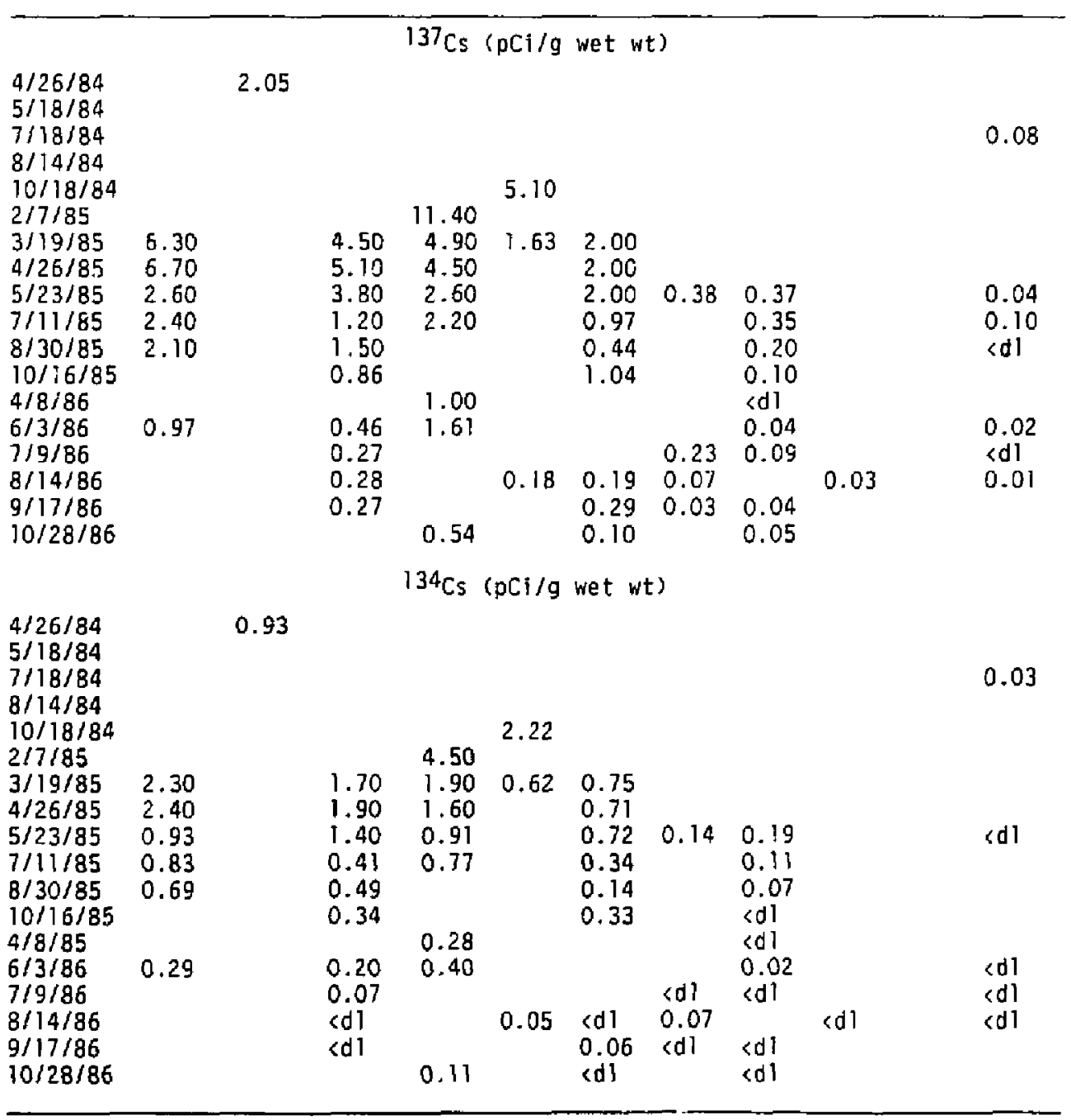




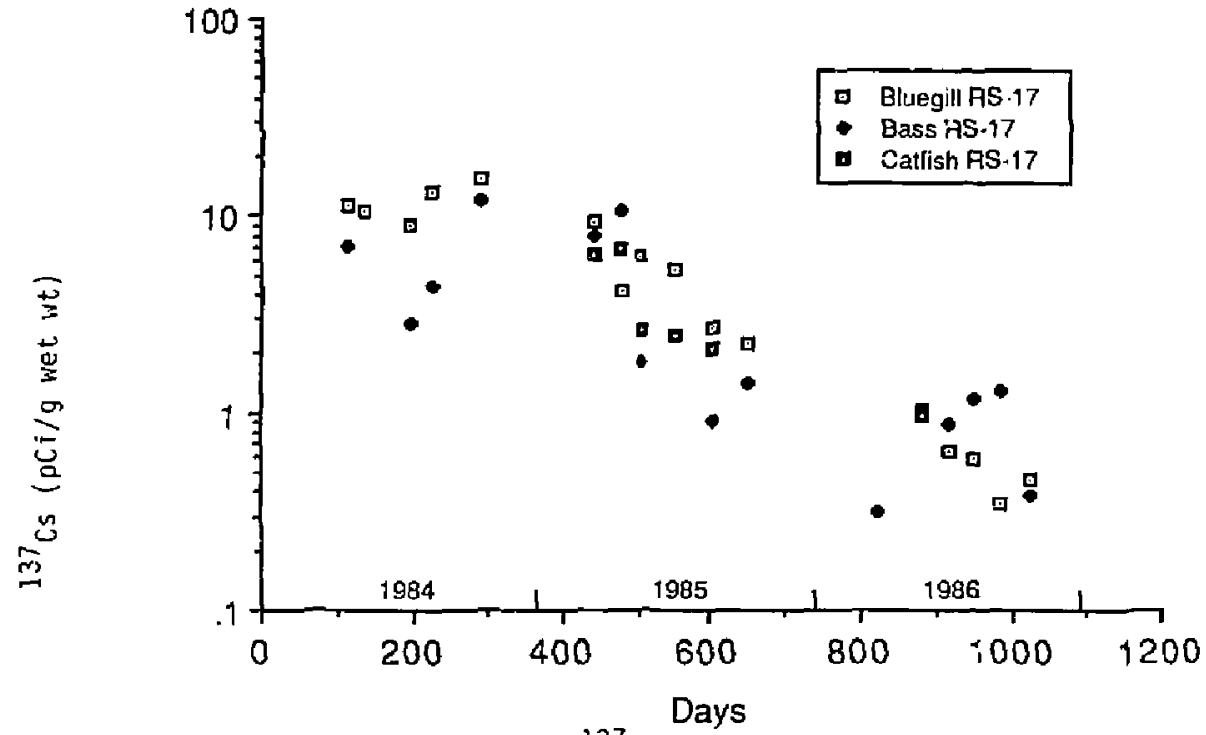

Figure 3. Mean concentration of ${ }^{137}$ Cs measured in flesh of biuegill, bass and catfish caught at Station RS- $77(0.5 \mathrm{~km}$ downstream from Rancho Seco) on days since Janirary 1 , 1984 .

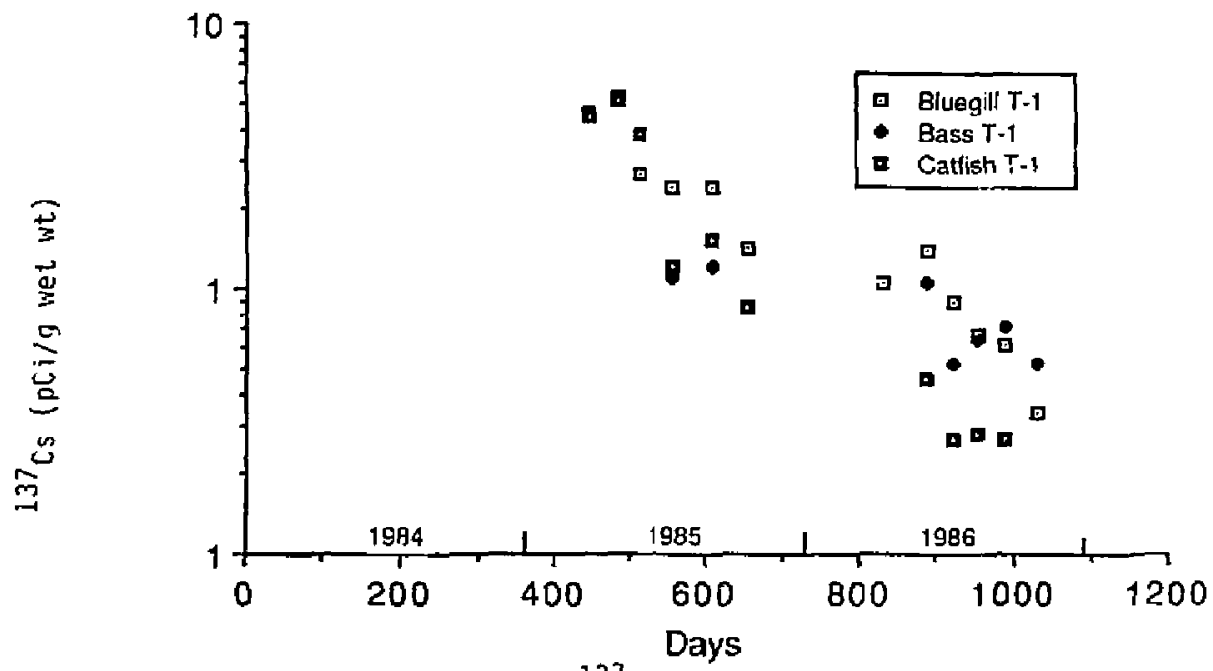

Figure 4. Mean concentration of ${ }^{137} \mathrm{Cs}$ meas!ıre; in flesh of bluegill, bass and catfish caught at Station T-1 $(3.0 \mathrm{~km}$ downstream from Rancho Seco) on days since January 1, 1984. 


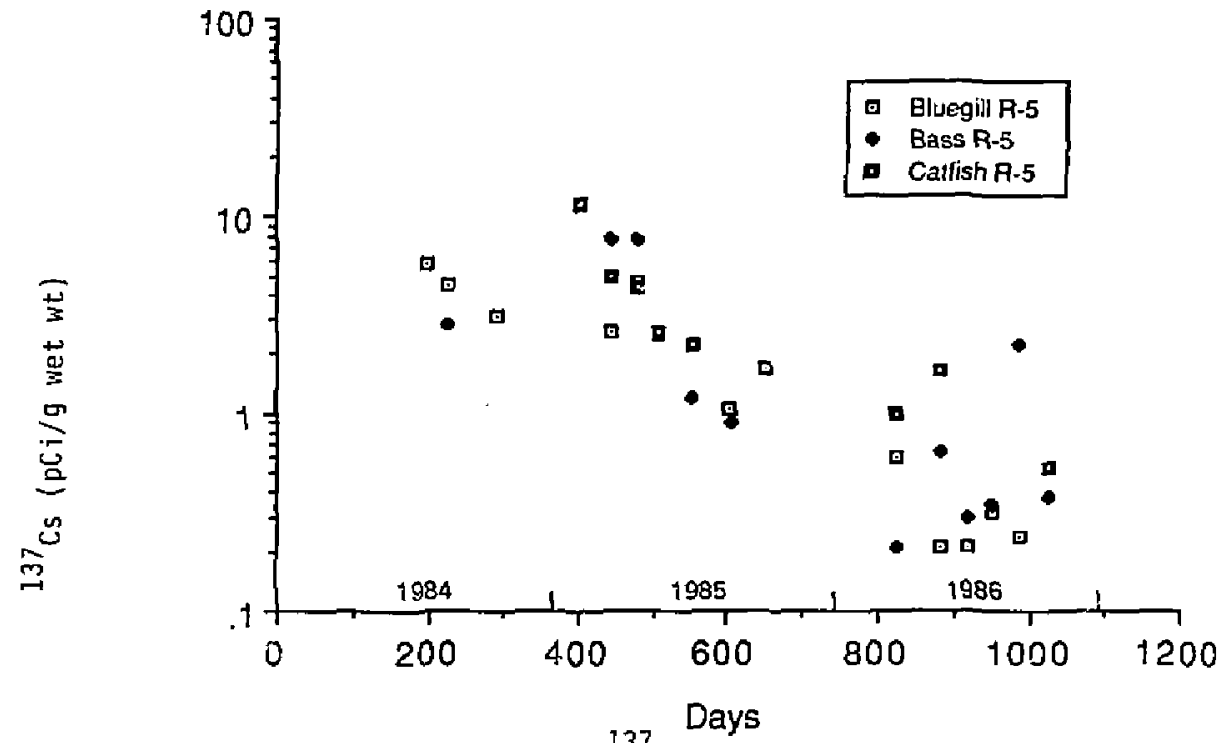

Figure 5. Mean concentration of ${ }^{137} \mathrm{Cs}$ measured in flesh of bluegili, bass, and catfish caught at Station $R-5(4.6 \mathrm{~km}$ downstream from Rancho Seco) on days since January $1,1984$.

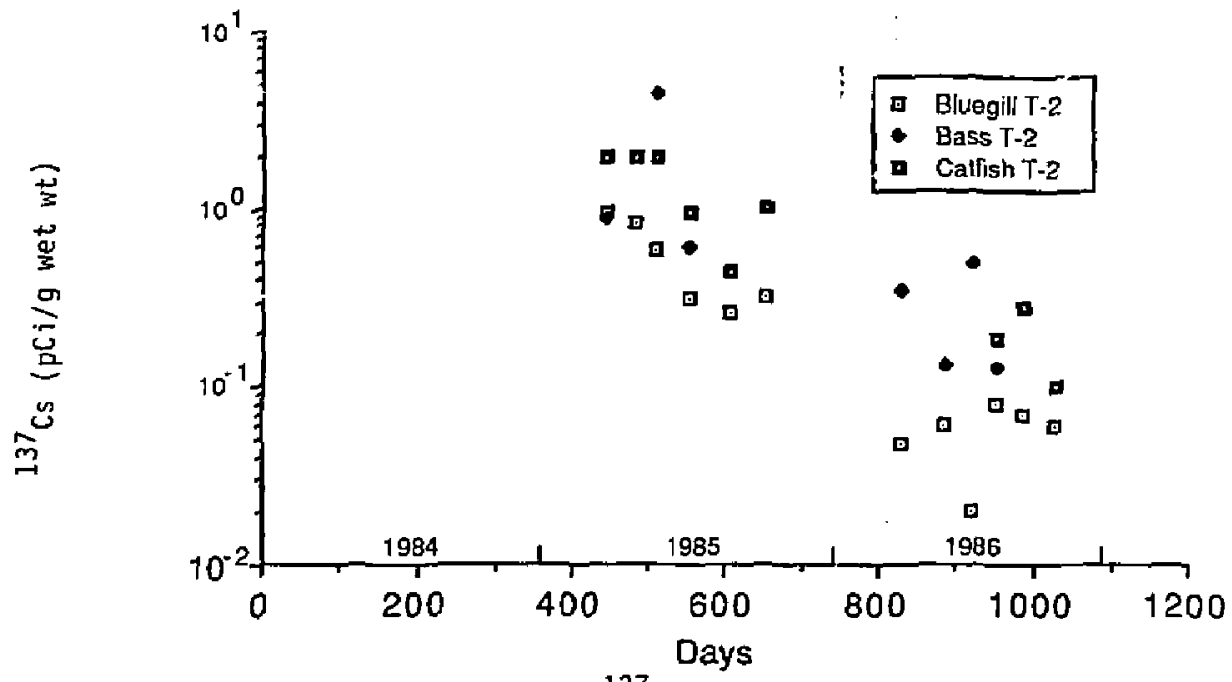

Figure 6. Mean concentration of ${ }^{137}$ Cs measured in flesh of bluegill, bass, and catfish caught at Station T-2 $(7.5 \mathrm{~km}$ downstream from Rancho Seco) on days since January 1, 1984. 


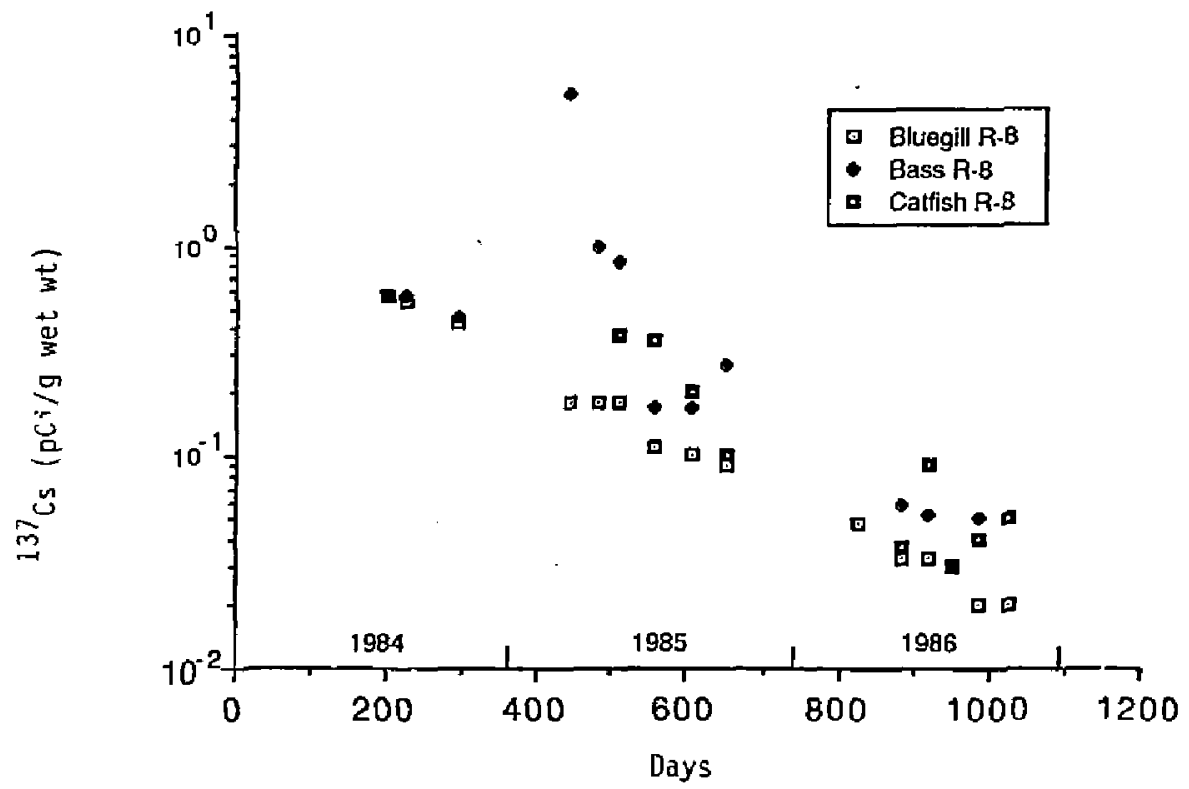

Figure 7. Mean concentration of ${ }^{137} \mathrm{Cs}$ measured in flesh of bluegil1, bass, and catfish caught at station R-8 (12.6 km downstream from Rancho Seco) on days since January $1,1984$.

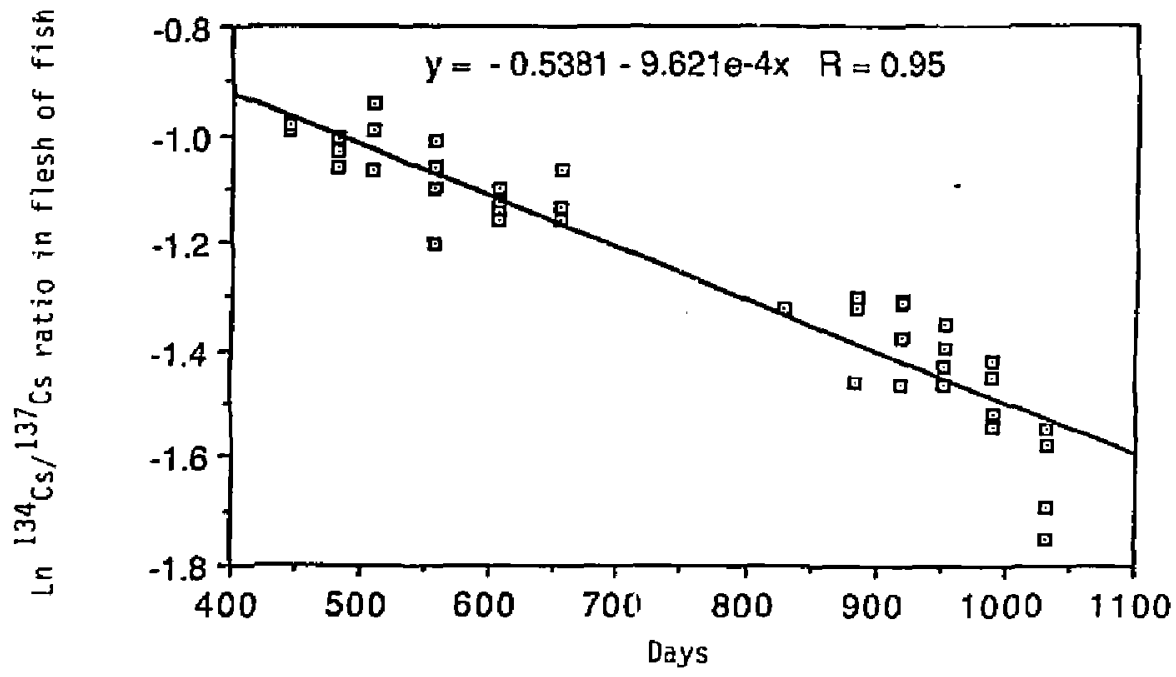

Figure $B$. ${ }^{134} \mathrm{Cs} /{ }^{137} \mathrm{Cs}$ activity ratio in fish from stations $\mathrm{RS}+17$ and $\mathrm{T}-1$ measured on days since January 1, 1984. Regression line has been fitted to the fata by the method of least squares. 


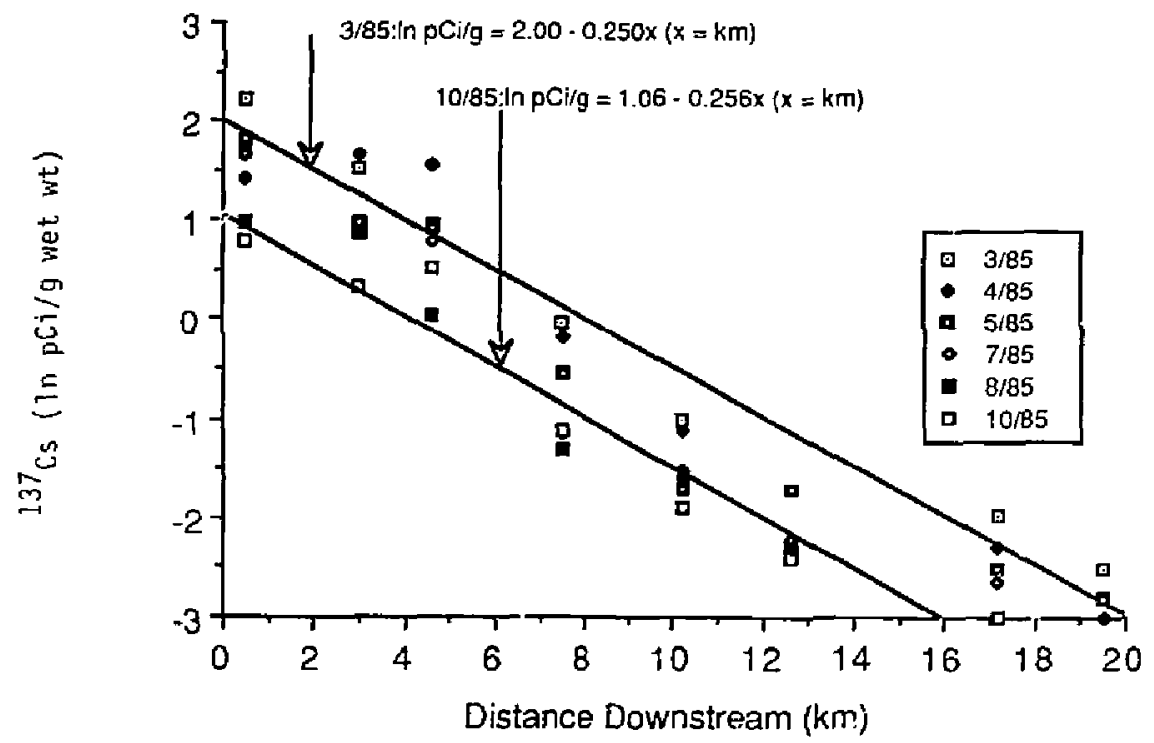

Figure 9. Concentration of ${ }^{137} \mathrm{Cs}$ in flesh of bluegii] caught in 1985 at different stations downstream from Ranzho Seco. Computed best fit to the March and October data is shown.

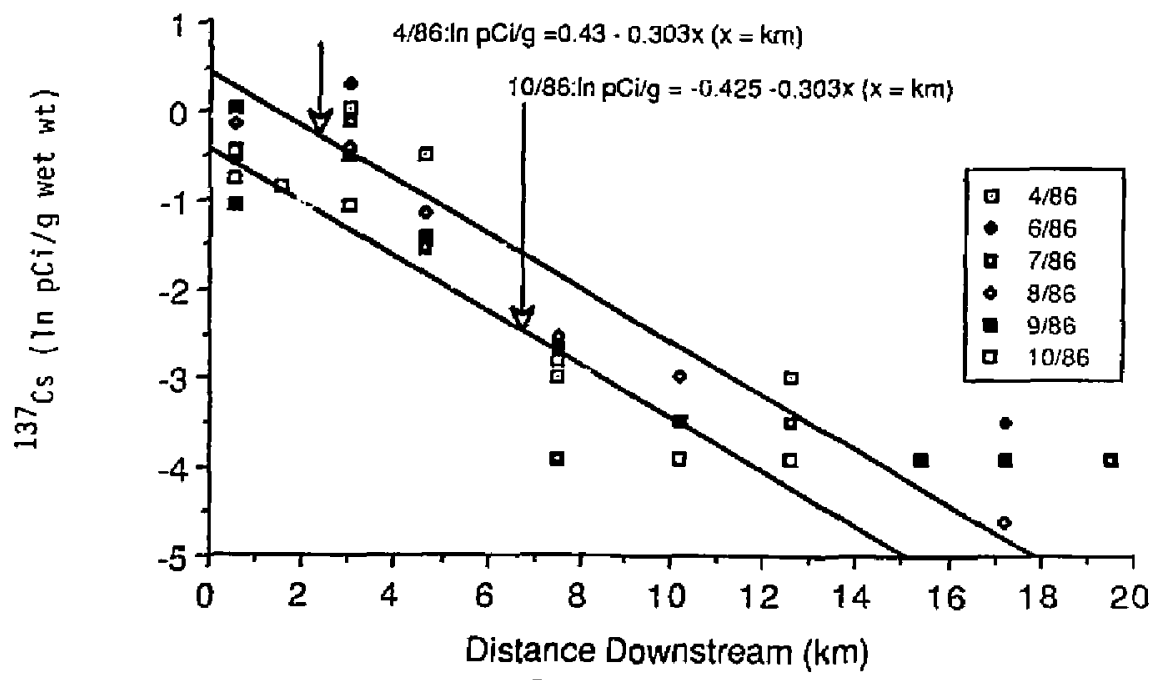

Figure 10. Concentration of ${ }^{137} \mathrm{Cs}$ in flesh of bluegill caught in 1986 at different stations downstream from Rancho Seco. Computed best fit to the April and October data is shown. 
Table 6 shows the average concentration measured in te flesh of all of the species of flsh caught at each downstream station in 1986. Highest average concentrations were measured in fish at station $2 \$-30$, an Irrigation pond connected to Clay Creek at station RS-17. The $r$ an concentration of ${ }^{137} \mathrm{Cs}$ in the flesh of all fish collected downstream $\mathrm{c}:$ station $\mathrm{T}-2$ (7.5 km from Rancho Seco) is $0.07 \pm 0.08 \mathrm{pCl} / \mathrm{g}$ wet wt. In most fish from locations below this station, the ievel of $134 \mathrm{Cs}$ was very low or below our detection limit. The mean value of $0.07 \mathrm{pCj} / \mathrm{g}$ is approximately $64 \%$ of the $0.11 \mathrm{pCi} / \mathrm{g}$ measured in fresh-water fish randonly sampled from market counters of Chicago, I11inois food stores in 1982 (9). The ${ }^{137} \mathrm{Cs}$ in fresh-water fish in Chicago markets orignates from world-wide global fallout. It is obvious that a computed, annual body dose-euvivalent rate to individuals from ${ }^{137} \mathrm{Cs}$ in fresh-water fish caught for consumotion in Laguna Creek, downstream from station T-2, would be comparable to or less than the computed dose from consumption of an equivalent quantity of fresh-water fish purchased in 1982 over the counter in Chicago, IL.

Measured concentrations of ${ }^{137} \mathrm{Cs}$ and ${ }^{134} \mathrm{Cs}$ in edibie frog legs and flesh of crayfish collected from downstream locations during 1986 are presented in Appendixes II and III. Concentrations of naturally occurring $40_{k}$ in the muscle of frog legs are also shown in Appendix II. No other gamma-emitting radionuclide associated with, the releases from Rancho Seco was detected in the edible fiesh of these organisms. Figure 12 shows the concentration of $137 \mathrm{Cs}$ in the flesh of frogs compared to that in biuegill flesh from all stations sampled during 1986. It is apparent from Fig. 12 that at each station the concentration of ${ }^{137} \mathrm{Cs}$ in bluegill flesh was either equivalent to or greater than the concentration in flesh of frogs. In the absence of downstream site-specific data for concentrations of ${ }^{1.57} \mathrm{Cs}$ in frogs, the levels in the flesh of bluegill and Equation (2) may be used with some certainty to estimate conservative values for mean concentrations during 1986 in these organisms ifrom any downstream location.

$137 \mathrm{Cs}\left(\rho \mathrm{Ci} / \mathrm{g}\right.$ wet wt frog) $=0.055+0.40 \times\left({ }^{137} \mathrm{Cs} \rho \mathrm{Cj} / \mathrm{g}\right.$ wet wt bluegi11)

ioo few crayfish were analyzed to develop any meaningful concentration ratios from the data with fish. 


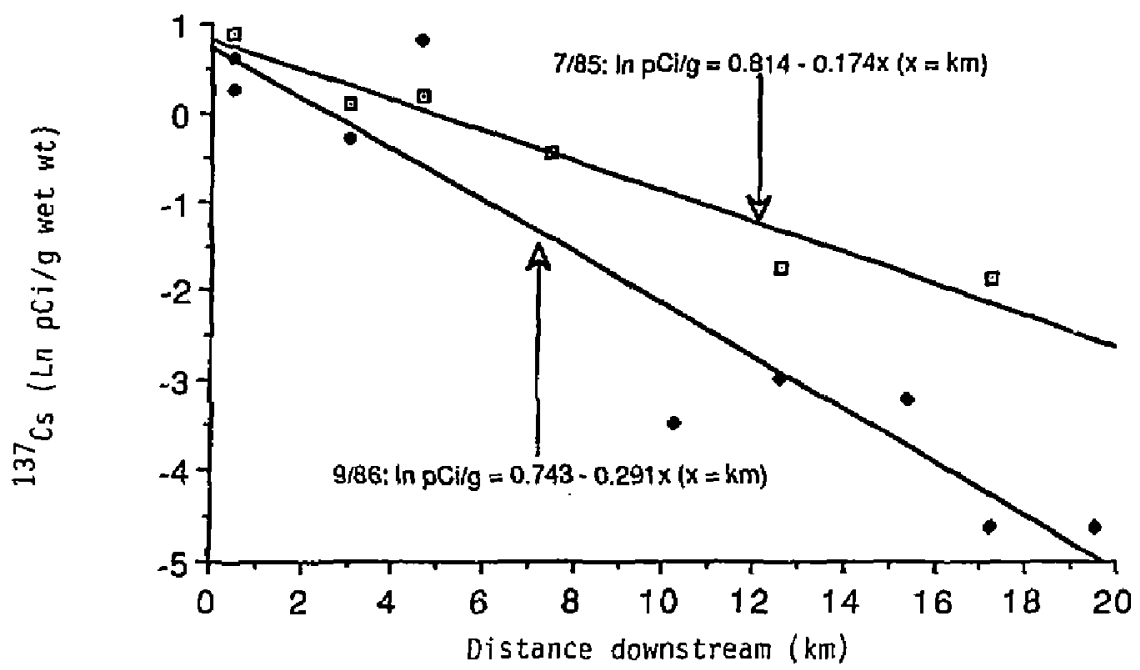

Figure 11. Concentrations of ${ }^{137} \mathrm{Cs}$ in flesh of bass caught during July 1985 and September 1986 at different stations downstream from Rancho Seco. Computed best fit to the data is shown.

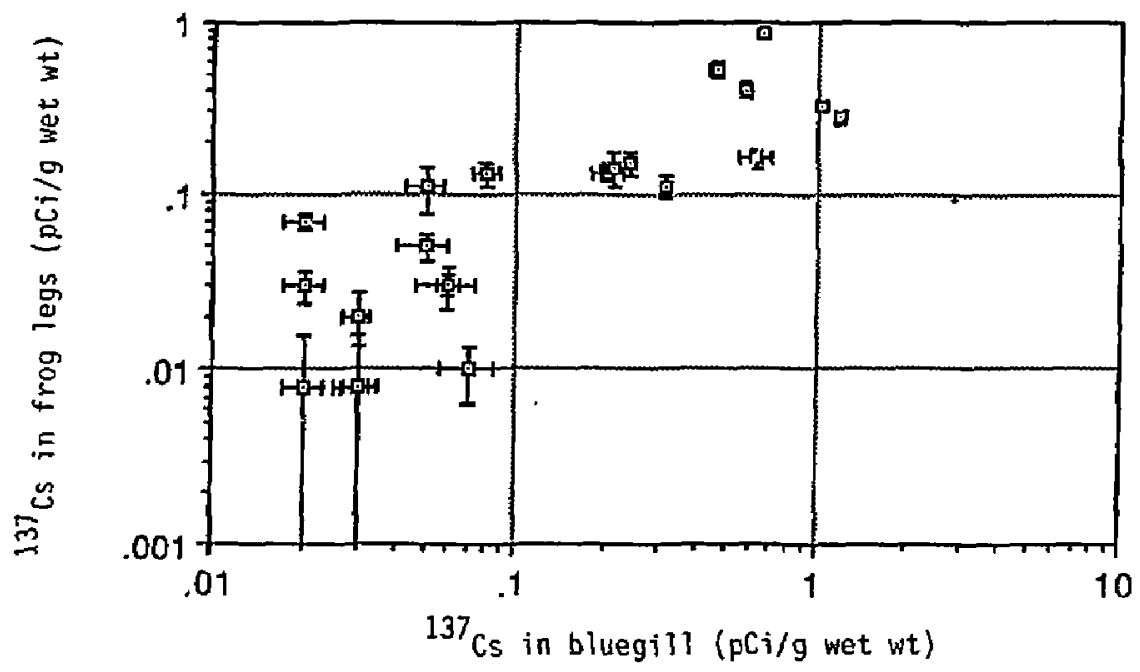

Figure 12. Concentrations of ${ }^{137} \mathrm{Cs}$ in flesh of bluegill and in frog legs collected during 1986 at stations downstream from Rancho Seco. 
Table 6. Mean concentration of ${ }^{137} \mathrm{Cs}$ and ${ }^{134} \mathrm{Cs}$ in the flesh of all fish collected at each downstream station in 1986.

\begin{tabular}{|c|c|c|c|}
\hline \multirow[b]{2}{*}{ Station } & Downstrean & \multicolumn{2}{|c|}{$\mathrm{pC} / / g$ wet $w t^{2}$} \\
\hline & distance $(\mathrm{km})$ & ${ }^{137} \mathrm{Cs}$ & $134 \mathrm{Cs}$ \\
\hline RS -17 & ú. 5 & $0.78 \pm 0.33(14)$ & $0.20=0.09$ \\
\hline RS-30 & 0.5 & $1.7 \pm 0.8(8)$ & $0.4 \pm 0.2$ \\
\hline$T-1$ & 3.0 & $0.7 \pm 0.6(16)$ & \pm 0.2 \\
\hline$R-5$ & 4.6 & $0.6 \pm 0.6(19)$ & $0.2 \pm 0.2$ \\
\hline$T-2$ & 7.5 & $0.15 \pm 0.14(18)$ & $0.05 \pm 0.04$ \\
\hline$T-3$ & 10.2 & $0.07 \pm 0.06(12)$ & $0.01=0.01^{b}$ \\
\hline$R-8$ & 12.6 & $0.05 \pm 0.02(17)$ & $0.02 \pm 0.01^{b}$ \\
\hline$R-22$ & 15.4 & $0.03 \pm 0.02(5)$ & $b$ \\
\hline$T-4$ & 17.2 & $0.03 \pm 0.03(6)$ & $b$ \\
\hline$R-11$ & 19.5 & $0.02 \pm 0.01(12)$ & $\mathrm{b}$ \\
\hline
\end{tabular}

a value in parenthesis is the number of samples averaged over the year.

b ${ }^{134} \mathrm{Cs}$ is below detection limits in the majority or in all samples. 
The concentrations of radionuclides determined in the creek sedinents sampled during 1986 are given in Appendix VII. Figures 13 to 15 show the concentrations of $137 \mathrm{Cs}$ in the 0 - to 12 -cri surface sediment sections collected in 1984, 1985, and 1986 from different downstream regions of $\mathrm{Clay}$, Hadselville, and Laguna Creeks. During each year, the concentrations associated with the sediments decrease more or less uniformly with increasing distance downstream from Rancho Seco. The equations stated in the figures best descrlbe the relationship between concentration and downstream distance. The coefficient for $x$, relating the change in concentration to downstream distance, is unchanged over the $3-y$ period and is identical to the coefficient describing the changes in concentration in bluegill (see Figs. 9 and 10) with downstream distance.

8etween 1985 and 1986 , the mean concentration of ${ }^{137} \mathrm{Cs}$ in the surface sediment at all downstream locations decreased, with an effective half-life of approximately 2 .

During October 1986, the highest concentration of $137 \mathrm{Cs}$ in surface sediment was measured in samples collected between stations RS-16 and RS-6, 0.6 to $1.6 \mathrm{~km}$ downstream from Rancho Seco. This is the region identified as a relative "hot" spot on the creek during the aerial radiological survey conducted by EG\&G in December $1984(10)$.

Concentrations for $40 \mathrm{~K}$ (a naturally occurring radionuclide) measured In surface sediments collected in 1986 are shown in Fig. 16. The differences encountered in the concentration of $40 \mathrm{~K}$ were quite unexpected. The mean concentration of $40 \mathrm{~K}$ in the surface sediment of clay creek (to a distance of $3.0 \mathrm{~km}$ from the plant), Hadselville creek (between 3.0 and $6.5 \mathrm{~km}$ downstream from the plant), and Laguna creek (between 6.5 and $20.5 \mathrm{~km}$ downstrean from the plant) are $4.7 \pm 1.4,14.4 \pm 2,3$, and $9.7 \pm 1.3 \mathrm{pCi} / \mathrm{g}$, respectively. It is not clear why concentrations in Clay Creek are low or why Hadselville Creek sediments contain higher levels of $40_{K}$ than Laguna Creek sediments. Clearly. the chemical composition of the sediments from each creek must differ. This difference must affect the binding capacity of the alkali metals, potassium $\left(40_{K}\right)$ and cesium $\left({ }^{137} \mathrm{Cs}\right.$ and $\left.{ }^{134} \mathrm{Cs}\right)$. It appears warranted to evaluate the $K_{d}$ 


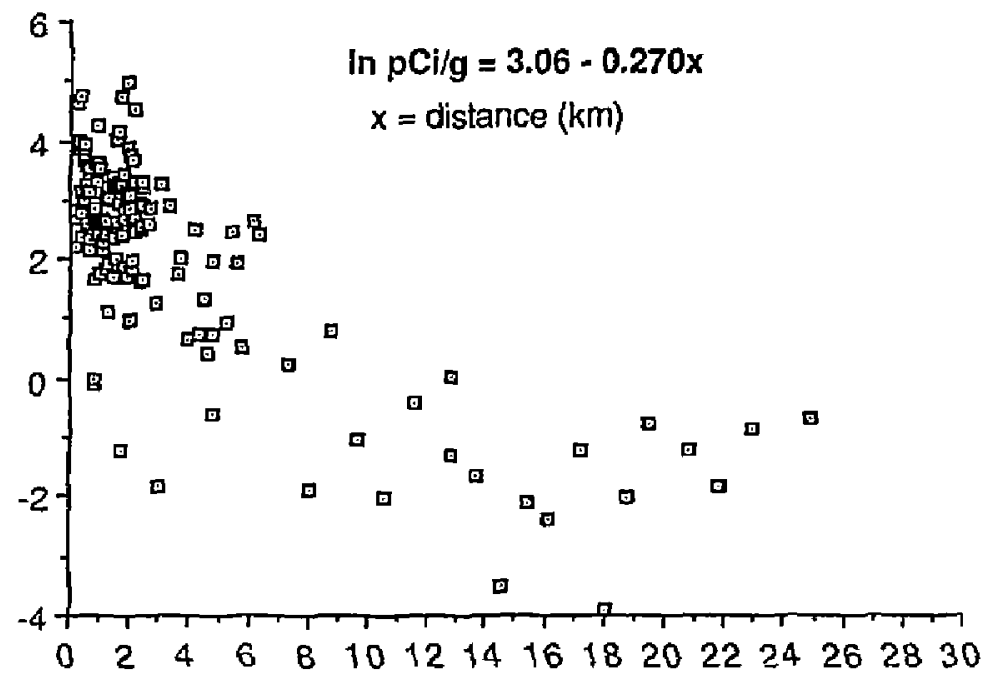

Distance Downstream $(\mathrm{km})$

Figure 13. Concentration of ${ }^{137} \mathrm{Cs}$ in surface $(0-12 \mathrm{~cm})$ sediment collected downstream from Ranch Seco during 1984. The equation results from a least-squares analysis of the measured concentration with downstream distance.

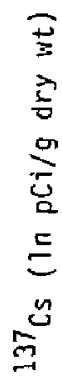

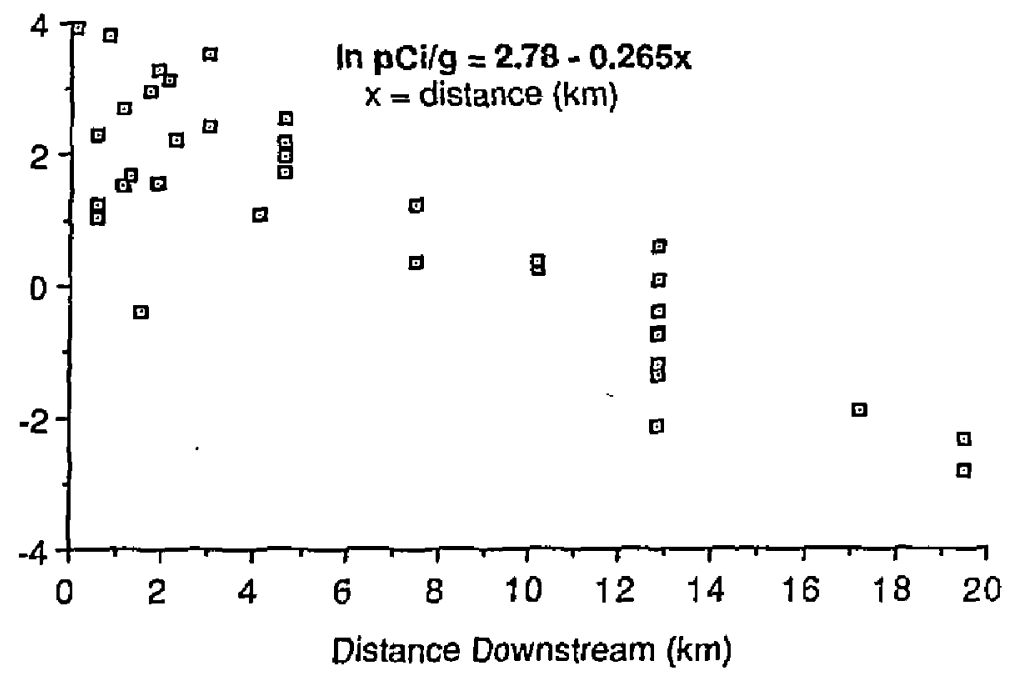

Figure 14. Concentration of ${ }^{137} \mathrm{Cs}$ in surface $(0-12 \mathrm{~cm})$ sediment collected downstream from Rancho Seco during 1985. The equation results from a least-squares analysis of the measured concentration with downstream distance. 


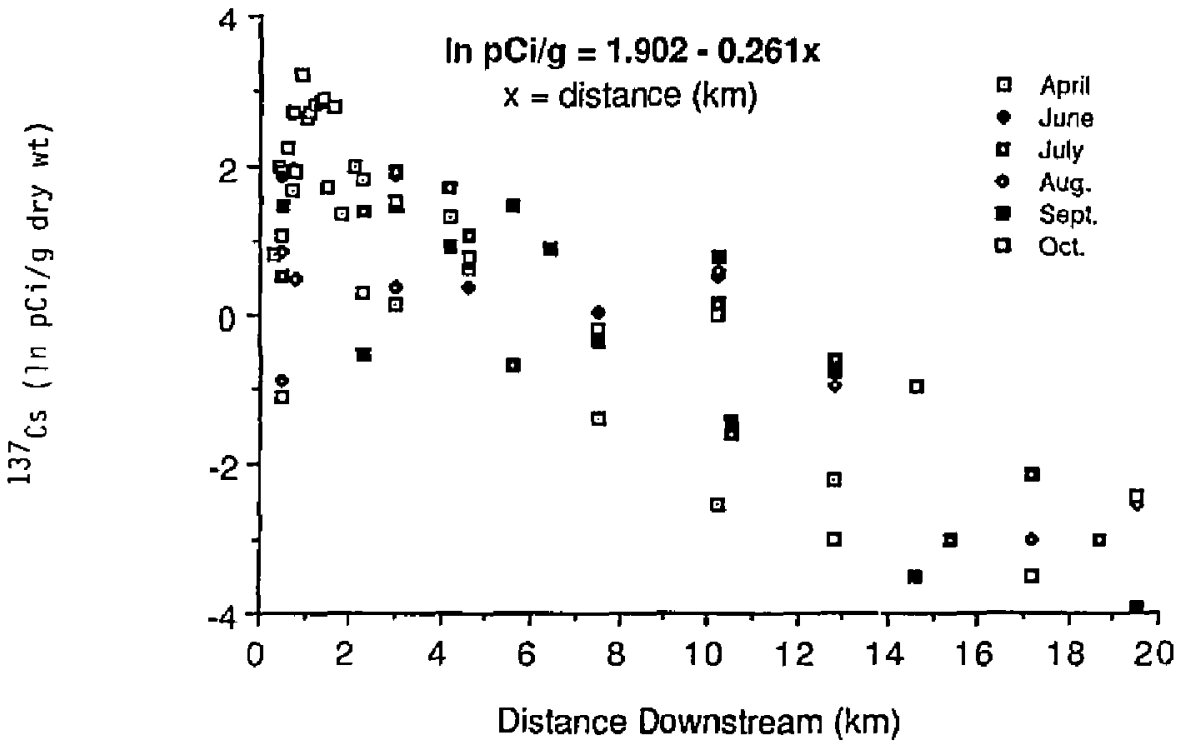

Figure 15. Concentration of ${ }^{137} \mathrm{Cs}$ in surface $(0-12 \mathrm{~cm})$ sediment collected downstream from Rancho Seco during 1986. The equation results from a least-squares analysis of the measured concentration with downstream distance.

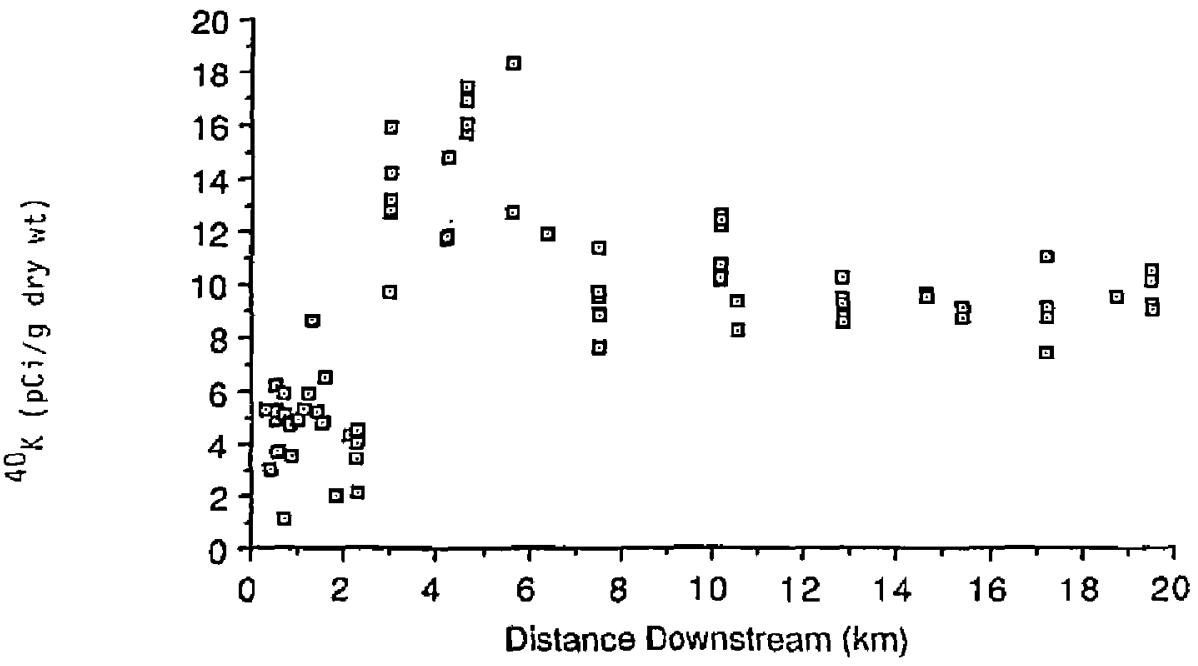

Figure 16. Concentration of ${ }^{40} \mathrm{~K}$ in surface $(0-12 \mathrm{~cm})$ sediment collected downstream from Rancho Seco during 1986. 
values for ceslum with sediment from the different creeks to better understand the partitioning of ${ }^{137} \mathrm{Cs}$ between water and the different sediments from the region.

A sediment core was collected to a depth of $24 \mathrm{~cm}$ from Station R-5 (4.6 km downstream from Rancho Seco) in April. The core was sectioned into 5-cm increments to determine the vertical distribution of the activity in the sediment column. Concentrations in the vertical sections are shown in the Appendix (Table VII-2). Similar concentrations of $137 \mathrm{Cs}$ are found in all depth increments of the core. This represents a change from 1984 when most sediment profiles showed a decrease in activity between the surface and depths. This recent sediment has been physically well mixed. The changes noted in surface concentrations with time may, in part, result from vertical mixing processes in which the higher surface concentrations measured in 1984 (see Fig. 15) have mixed with low concentrations from the lawer depths. A core from this location in 1984 conicained $7.1 \mathrm{pCi} / 9$ of ${ }^{137} \mathrm{Cs}$ in the surface layer (4). In the 1986 core, the surface concentration is $1.53 \mathrm{pCi} / \mathrm{g}$. This represents a $79 \%$ reduction in the surface concentration over $2 \mathrm{y}$. However. the integrated amounts of ${ }^{137} \mathrm{Cs}$ in the 1984 and 1986 sediment column were 82 (4) and $71 \mathrm{pCi} / \mathrm{cm}^{2}$, respectively, to the maximum depth sampled. The integrated inventory of ${ }^{137} \mathrm{Cs}$ decreased only $i 3 \%$ over this time period, suggesting that the majority of 137 Cs previously accumulated by the sediment deposits has been mixed to deeper depths within the sediment column. He can hardly make a serjous case for this burial mechanism on the basis of results from a single comparison, and we recommend that additional studies be undertaken on sediment core samples to better assess the fate of ${ }^{137} \mathrm{Cs}$ in this e.vi fronment.

\section{Concentrations of Radionuclides in Creek Water Samples}

Concentrations of ${ }^{134} \mathrm{Cs}$ and $137 \mathrm{Cs}$ in filtered creek water samples and in the separated particulate material from downstream locations are shown in Appendix IV. The small quantities now present in solution origlnate from plant releases, from creek sediments by remobilization, and from agricultura? run-off in areas where creek water was prevlously used for irrigation. 
An NRC (Nuclear Regulatory Comission) inspection at Rancho Seco in Apri) 1986 caused the district to reevaiuate the 1985 radioactive liquid-effluent discharges. The district now reports discharges to Clay Creek of $4 \mathrm{mCl}$ of ${ }^{137} \mathrm{Cs}$ for 1985 and $0.7 \mathrm{mCi}$ of ${ }^{137} \mathrm{Cs}$ for the first half of 1936 (1).

Station RS-i7 is $0.5 \mathrm{~km}$ below the plant outfall on Clay Croek at the western boundary of the site. We have made collections and analysis of water from this site since the spring of 1984. The different concentrations of total ${ }^{137} \mathrm{Cs}$ (dissolved and particulate fraction) measured in water samples collected from this station on days since January 1, 1984, are shown in Fig. 17. Figure 18 shows the percentage of the total 137 Cs measured in solution on the respectlve sampling days. The mean concentration measured in solution at this station during 1984 was $2.8 \pm 21 \mathrm{pCi} / 1$ (5). During 1985 and 1986. the mean concentrations in solution were $0.47 \pm 0.43$ and $0.05 \pm 0.04 \mathrm{pCl} / 1$. respectively. Because releases from the plant posslbly occurred during periods when we were not sampling, these values do not necessarily represant a true mean concentration for the entire year: they are useful only to show the general trend in the change occurring in the concentration over time. The results are, however, an independent illustration of the effectiveness of the district initiated liquid-effluent control program. It is of interest, to note that the $4 \mathrm{mCl}$ of $137 \mathrm{Cs}$, which was reported released in 1985 (1). was discharged with $10.1 \times 10^{9} \mathrm{~L}$ of dllution water to Clay creek. Therefore, the average concentration in water discharged from the plant over the year was $0.41 \mathrm{pCi} / \mathrm{L}$; a value in good agreement with our mean value of $0.47 \mathrm{pCi} / \mathrm{L}$ at station RS-17 on Clay Creek.

Since 1984, we have consistently found that the concentration of ${ }^{137} \mathrm{Cs}$ in water sampled as far as $10 \mathrm{~km}$ downstream was equivalent to or greater than the concentration measured at station RS-17 at the site boundary. This clearly would not be the case during the inittal stages of a release from the plant. Figures 19 and 20 show the concentrations measured at downstream locations normalized to the concentration measured $1 \mathrm{n}$ solution at RS-17 for 1984 ar.d 1985 (Fig. 19) and 1986 (Fig. 20). The pastern is repeated monthly during each year, regardless of the absolute concentration in the water. During 1984, 1985, and January to September 1986, higher concentrations were found in water sampled at stations $T-1$ (3.0 km downstream) and $R-5$ (4.6 km downstream) than at station RS-17. The higher concentrations in water persist to at least $10 \mathrm{~km}$ downstream. 


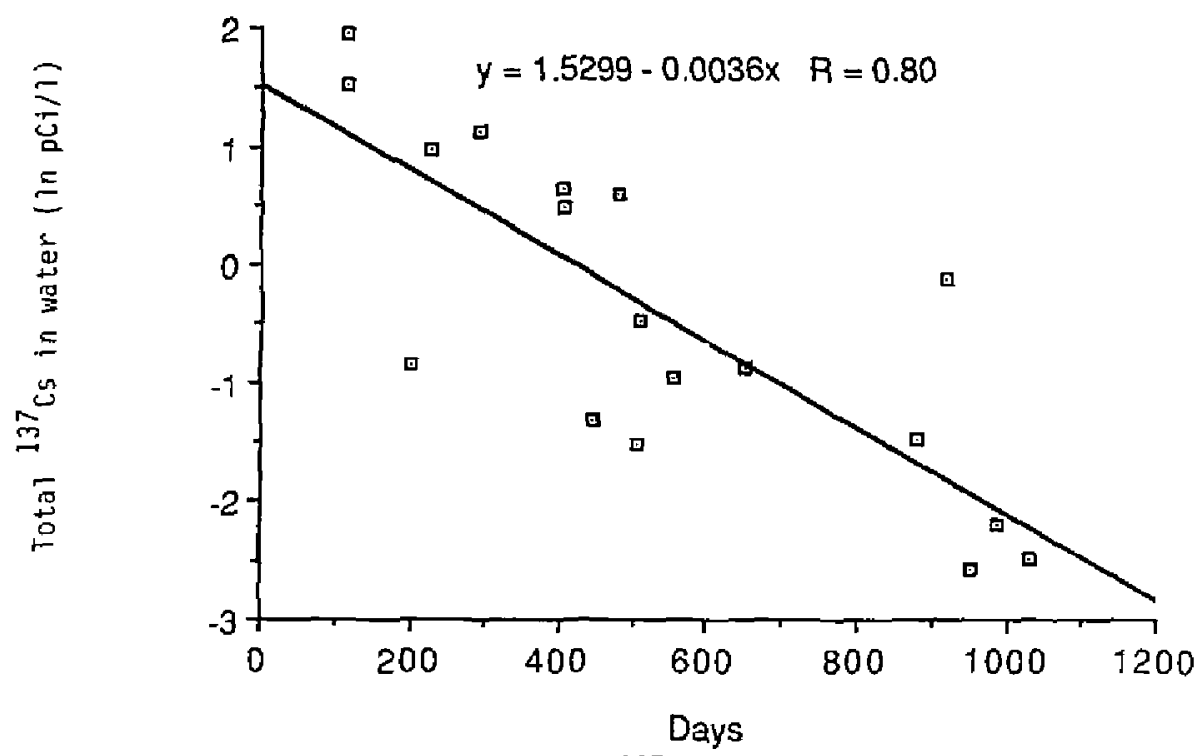

Figure 17. Concentration of total ${ }^{137} \mathrm{Cs}$ in water samples coliected at Station RS-17 (0.5 km downstream of Rancho 5 eco) on days since January I, 1984 .

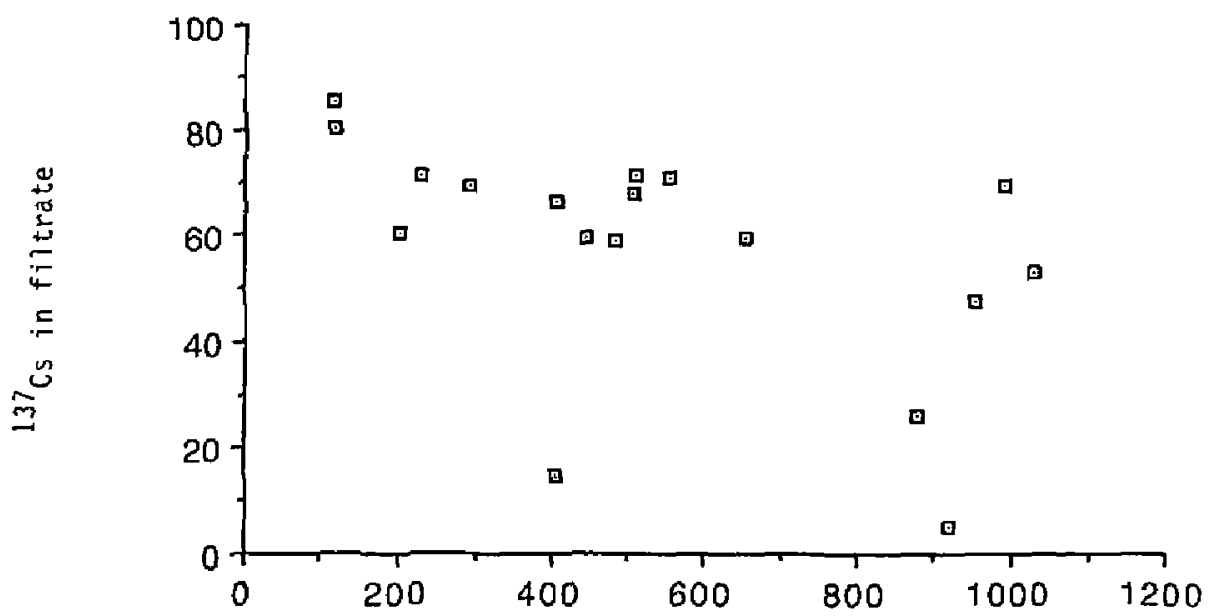

Figure 18. Percentage of tota ${ }^{137} \mathrm{Cs}$ in filtrate at Station RS-17 on days since January $1,1984$. 


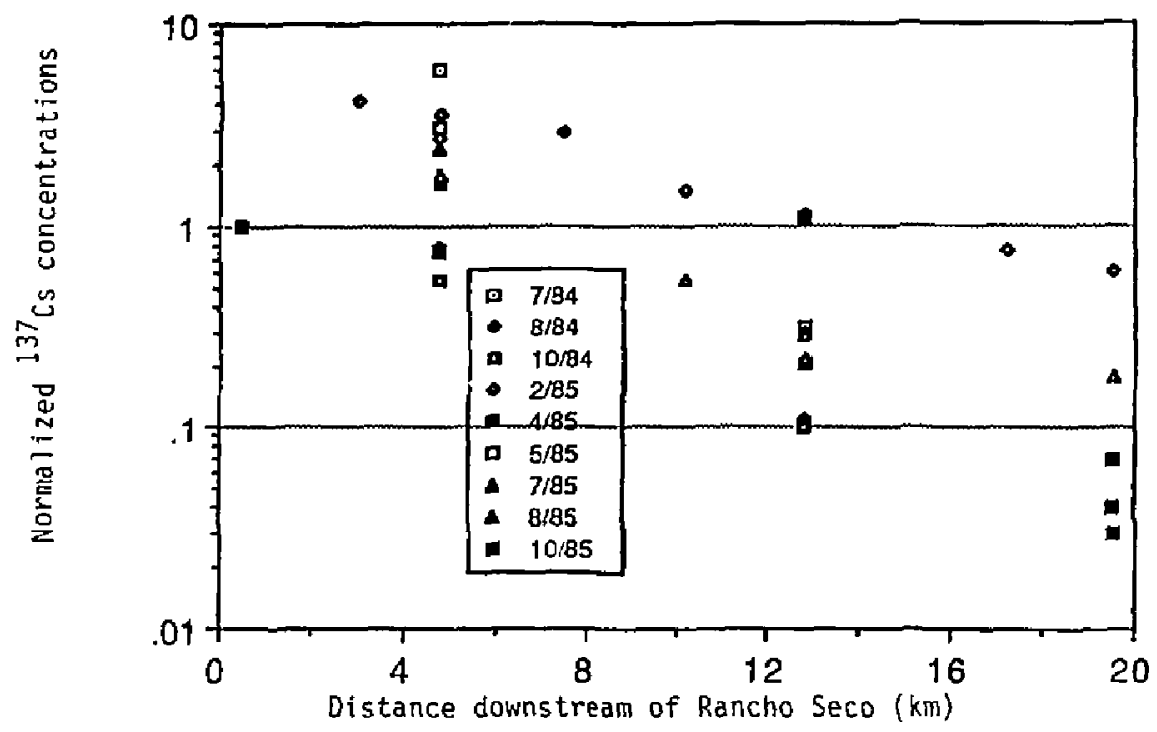

Figure 19. Concentration of ${ }^{137} \mathrm{Cs}$ in filtered water collected at downstream stations in 1984 and 1985 normalized to the concentratian at station RS-17 $(0.5 \mathrm{~km}$ from Rancho Seco).

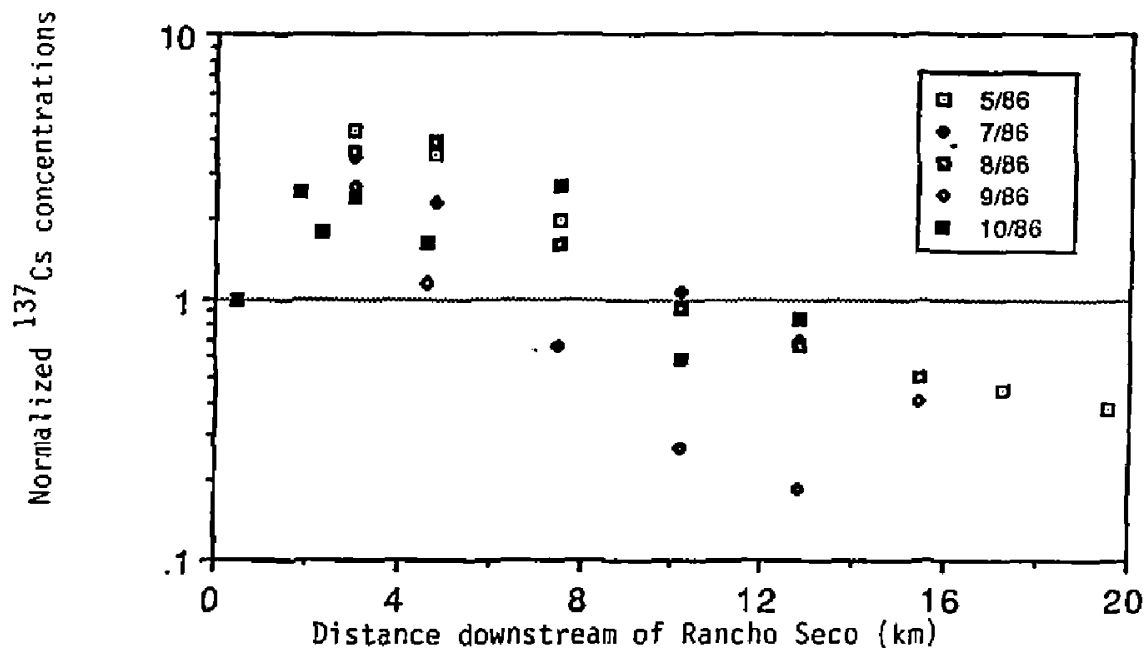

Figure 20. Concentration of ${ }^{137} \mathrm{Cs}$ in $1 \mathrm{jlt}$ tered water collected at downstream stations in 1986 narmalized to the cancentration at Station RS-17 $10.5 \mathrm{~km}$ from Ranch Seco). 
In October 1986, we looked for another possible source of ${ }^{137} \mathrm{Cs}$ between stations RS -17 and T-1. Station RS-5 (1.8 km downstream from the plant) is the region of $\mathrm{Clay}$ Creek that had previously been identified as a relative hot spot on the creek during the EG\&G aerial survey in 1984 (10). In Dctober, we measured higher concentrations at this location and identified an irrigation pipe that drained excess irrigation water to the creek from the adjacent field. Since 1981 (when $137 \mathrm{Cs}$ was first reported in liquid effluents from Rancho Seco), this field had been irrigated with water pumped from station RS-17. The excess water was discharged to the creek at 5 tation RS-5, $1.3 \mathrm{~km}$ downstream from the irrigation pump. Some of the ${ }^{137} \mathrm{Cs}$ previously applied to the field witi: irrigation water is mobilized by the application of irrigation water in later years. The irrigation water also erodes some soil that is subsequentiy transported to the creek at station RS-5. The eroded solids may contribute to the higher sediment concentrations that we now find in this region of the creek and to the elevated activity seen in this region during the EG\&G flyover (10). This source also contributes to the inventory of $137 \mathrm{Cs}$ immediately downstream of RS-5. However, because the concentration of $137 \mathrm{Cs}$ in the water is lowered further downstream by dilution (from field drains and other sources), this source cannot be entirely responsible for the higher levels in water to a distance of $10 \mathrm{~km}$ downstream.

\section{Concentration Factors}

Another reason for the continued collection of water samples is to strengthen aur data base on concentration factors for ${ }^{137} \mathrm{Cs}$ for the species of fish in the creek. Over the last 3 years, we have consistently found that the concentration factor for ${ }^{137} \mathrm{Cs}$ in the flesh of fish caught nearest the plant was larger than the concentration factor for fish caught further downstream.

The concentration factor is the ratio of radionuclide concentration in the organism or tissue to that in the water. Concentration factors were computed from the mean concentrations of $137 \mathrm{Cs}$ in fish muscle and the appropriate filtered-water concentration measured in 1984, 1985, and 1986 at the different stations. Median and mean (and the standard deviation of the arithmetic mean) values for the concentration factors were computed for ${ }^{137} \mathrm{Cs}$ in fish from Clay, Hadselville, and Laguna Creeks. The results are shown in Table 7 . These values are not necessarily equilibriun concentration factors. 
Table 7. Median and mean values for concentration factors (CF) for ${ }^{137} \mathrm{Cs}$ in bluegill, bass, and catfish.

\begin{tabular}{|c|c|c|c|c|c|c|c|c|c|}
\hline & \multicolumn{3}{|c|}{ Clay Creek } & \multicolumn{3}{|c|}{ Hadselville Creek } & \multicolumn{3}{|c|}{ Laquna Creek } \\
\hline & No. a & $\begin{array}{l}\text { Median } \\
\text { CF } \times 10^{-3}\end{array}$ & $\begin{array}{c}\text { Mean } \\
\text { CF } \times 10^{-3}\end{array}$ & No. a & $\begin{array}{l}\text { Median } \\
\text { CFxio-3 }\end{array}$ & $\begin{array}{c}\text { Mean } \\
C F \times 10^{-3}\end{array}$ & No.a & $\begin{array}{l}\text { Median } \\
\text { CF } \times 10^{-3}\end{array}$ & $\begin{array}{c}\text { Mean } \\
\mathrm{CF} \times 10^{-3}\end{array}$ \\
\hline Bluegill & 15 & 14 & $16 \pm 8$ & 21 & 3.2 & $3.6 \pm 0.5$ & 31 & 1.4 & $1.5 \pm 0.1$ \\
\hline Bass & 15 & 8.9 & $13 \pm 3$ & 16 & 3.4 & $5.3 \pm 1.5$ & 29 & 2.1 & $3.5 \pm 1.0$ \\
\hline Catfish & 6 & 11.4 & $15 \pm 5$ & 13 & 3.3 & $5.2 \pm 1.2$ & 18 & 2.9 & $2.9 \pm 0.4$ \\
\hline
\end{tabular}

a The number of samples averaged. 
The standard deviations show that differences were encountered among the individual values; an explanation for these differences is that the concentration in water is measured in samples taken on a specific date, while the fish may have encountered different concentrations in the water or food for an extended period prior to sampling. However, by repeating the measurements a number of times over the years, as we have done, the mean values shown are probably quite close to being true equilibrium concentration factors.

It is appropriate to find differences in concentration factors for ${ }^{37} \mathrm{Cs}$ among the different species of fish (biuegill, bass, and catfish). The differences among species are caused by a number of factors. It was unexpected, however, to find different concentration factors for ${ }^{137} \mathrm{Cs}$ in the same species of fish from dffferent locations (in Table 7 , compare values for bluegill from $\mathrm{Clay}$ and Laguna Creeks). Figures 9 and 10 show that concentrations in the flesh of bluegill decrease with distance downstream. However, Figs. 19 and 20 show that the concentration in water as far as $10 \mathrm{~km}$ downstream was equivalent to or greater than the concentration in water at the site boundary (Station RS-i7). If concentrations of ${ }^{137} \mathrm{Cs}$ in $\mathrm{fish}$ were only related to the levels in water, the measured concentration factors should be identical (or greater) for fish collected between the site boundary and $10 \mathrm{~km}$ downstream. This is not the case for the bluegili, bass, and catfish from Clay, Hadselville, and Laguna Creeks.

\section{Concentrations of Stable Potassium}

Vanderploeg et al. (11) had previously reported that the concentration factor for ${ }^{137} \mathrm{Cs}_{5}$ is influenced by the stab? a notassium in fresh water. They recommended an upper-bound bloaccumulation factor to predict cesium concentration in non-piscivorous fish ( $\mathrm{fn}$ this case bluegill) of $5 \times 10^{3} / \mathrm{kpm}$. if the stable potassium level is known.

In October 1985. we collected a series of water samples for stable potassium analysis. The potassium was determined by measurements with atomic absorption. Our results are shown in Fig. 21 along with the concentrations measured in water in samples subsequentiy collected in 1986. In October 1985. the levels of potassium in the water sampled from Clay and Hadselville Creeks were ruch less than the concentrations measured in Laguna Creek. These 
results were unexpected but showed that there could be ancther factor influencing the amount of ${ }^{137} \mathrm{Cs}$ accumulated by the fish. Potassium was measured in water collected from the creeks during April. May, and July 1986. Figure 21 shows that the concentrations measured during these periods generally increased with distance downstream from Rancho Seco.

The source of this additional potassium was not obvious. In July 1986 , we sampled a series of irrigation drains that were located along the creek. During July, the amount of water draining from the irrigated fieids through these drains to the creek was significant. The water originates from wells or reservoirs and is used to irrigate crops during the growing season. Flow rates over the year from the fields are irregular; they depend on the time of year and the amount of water applied for irrigation. The concentration of potassium in the water sampled at downstream locations of the creek and at the field drains during July are shown in Fig. 22. Water from several drains at approximately 4 and $13 \mathrm{~km}$ downstream contained elevated levels of potassium. Mixing of the drainage water with the creek water resulted in graduated increases in the concentration of potassium in the water. The different potassium levels in the water probably originate from high potassium fertilizers that were applied to the fields during the planting season.

Between April and July 1986, the mean potassium level in creek water at the plant boundary (Station RS-17) was $0.77 \mathrm{ppm}$. At 5 and $16 \mathrm{~km}$ downstream, the mean potassium concentration was 1.35 and $2.5 \mathrm{ppm}$, respectively. The predicted concentration factors (using the Vanderploeg et al. (1i) relationship) for cesium in bluegill from the measured potassium concentrations are 7000,3700 , and 1100 at $0.5,5$, and $16 \mathrm{~km}$, downstream from Rancho Seco. The median values, shown in Table 7, for the ${ }^{137} \mathrm{Cs}$ concentration factors for blueglll of 14000 for Clay Creek $(0.5 \mathrm{~km}), 3200$ for Hadselville Creek ( $5 \mathrm{~km})$, and 1400 for Laguna Creek (16 km) are in reasonable agreenent with these values. Although there are somewhat higher ${ }^{137} \mathrm{Cs}$ levels in the water below the site boundary, the higher potassium levels in the wacer plays a major role in regulating the amount of the cesium radionuclides accumulated by fishes at downstream locations.

Figure 22 shows that in July, water with a relatively high potassium concentration entered the creek (through field drains) between 4.0 and $4.6 \mathrm{~km}$ downstream from Rancho Se 0 . This location is between the plant boundary (RS-17) and Station R-5. There are other fleld drains between these stations 


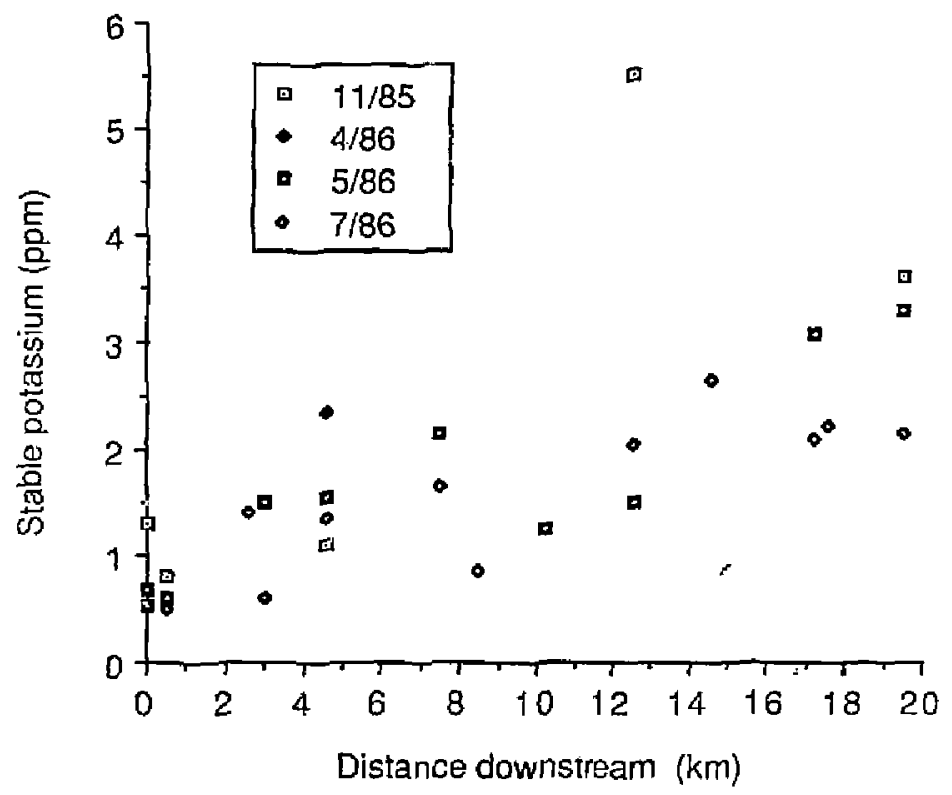

Figure 21. Concentrations of stable potassium in creek water sampled at different times and different locations downstream from Rancho Seco.

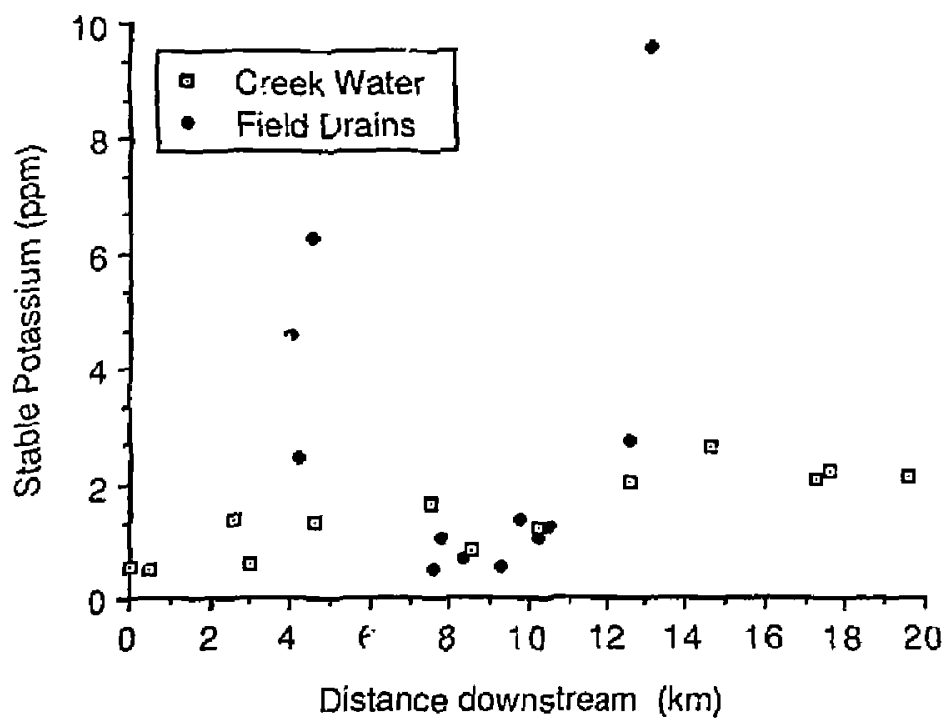

Figure 22. Concentrations of stable potassium in creek and field-drain water s:mpled in July 1986 at locations downstream from Rancho Seco. 
where flowing water (possibly containing increased levels of potassium) was encountered but not sampled. These higher potassium concentrations must displace a fraction of $137 \mathrm{Cs}$ sorbed to the sediments, causing the $137 \mathrm{Cs}$ concentrations in water to increase. This labeled water flows downstream; consequently, higher concentrations would be found in solution at Stations T-1, R-5, and other downstream locations. This ${ }^{137} \mathrm{Cs}$ remobilization mechanism (caused by increased potassium levels in water) persists during years of high- and low-level releases from the piant. Release of $137 \mathrm{Cs}$ from sediments will occur at all downstream locations; the quantities mobilized will be regulated by potassium concentrations in water. The literature indicates that cesium can be displaced from some soils by potassium, but the rates and quantities are probably site specific and should be determined locally. Because potassium wtll compete for binding sites with the sediment-bound cesium, increased potassium concentrations may offer a solution to "cleaning-up" some residual cesium from the creek surface sediments.

\section{Concentrations of Radionuclides in Leaves of Water Hyacinth}

Water hyacinth (Eichhornia crassipies) collection was initiated in 1985 to evaluate the usefulness of the plant as an indicator species for future monitoring of the waterway. The concentrations of the radionucilides detected by gamma spectrometry in the stem-leaf sections of the plants collected from different downstream stations are shown in Appendix VI. In addition to accumulating ${ }^{134} \mathrm{Cs}$ and $137 \mathrm{Cs}$, the plant accumulates $54 \mathrm{Mn}$ and ${ }^{60} \mathrm{Co}$, making it a usefui indicator species during the spring to fall months for a variety of different radionuclides released from Rancho Seco.

No radionuclides originating from Rancho Seco releases were found in plants (or in water nor flsh) sampled from Skunk Creek, flowing to the south of and parallel to Laguna creek. (There has been speculation that exchange of water occurs between the two creeks, especially during the rainy season. On the basis of our measurements of radionuclide tacers, we do not believe that such an exchange occurs.)

The data indicate that the leaves of the plant may obtain a significant fraction of the measured radionuclides by direct uptake from water. ${ }^{60} \mathrm{Co}$, for example, was found in the majority of surface sediments sampled as far as $4.5 \mathrm{~km}$ downstream from Rancho Seco. This radionuclide is continuously 
available to the roots of plants growing in this region. Yet only ouring May and July was ${ }^{60}$ Co above detection limits in the leaves of plants between 3 and $4.5 \mathrm{~km}$ downstream from Rancho Seco. Small quantities of 60 Co must have been released to the water in the creek during early summer and accumulated by the hyacinth. Between July 8 th and August 13 th, the quantities of 60 Co originally accumulated by the plants sampled between 3 and $4.5 \mathrm{~km}$ downstream, were absent, implying a rapid turnover rate in this plant for this radionuclide.

Concentrations of ${ }^{137} \mathrm{Cs}$ in the plant varied more over the seasons than concentrations in fish or water. The plant seems to act as an indicator of specific releases from Rancho Seco rather than as a long-term integrator. The computed, mean concentration factors for ${ }^{137} \mathrm{Cs}$ accumulated by the plants from Station RS-17 (0.5 km from Rancho Seco), Station T-1 (3.0 km), Station R-5 $(4.6 \mathrm{~km})$, and Station $R-8(12.6 \mathrm{~km}\rangle$ are $6100,600,700$, and 700 , respectively. As with fish, we find the highest concentration factor is associated with plants sampled from clay creek. Potassium in the water must aiso play a role in regulating the uptake of $137 \mathrm{Cs}$ (and $134 \mathrm{Cs}$ ) by the water hyacinth.

\section{Concentration of Radionucildes in Soli Samples}

Soil samples were collected for analys is from different locations during the year. Concentrations of the different radionuclides measured in the samples are shown in 4 tables of Appendix VIII.

In late 1984, the NRC sponsored an environmental radiological survey of the region around Rancho Seco (12). As part of this survey, a number of surface ( 0 to $5 \mathrm{~cm}$ ) soil samples were collected from locations selected to have typical background levels of radioactivity for the general ar:?. Fallout background concentrations of $137 \mathrm{Cs}$ determined in 12 samples ranged from 0.04 to $1.3 \mathrm{pCi} / \mathrm{g}$. "Concentrations of radionuclides in soil at background locations averaged $0.41 \mathrm{pCi} / \mathrm{g}$ of $137 \mathrm{Cs}$, effectively zero $\mathrm{pCi} / \mathrm{g}{ }^{134} \mathrm{Cs}, \ldots .$. (12). Tables 1,2, and 3 of Appendix VIII show the levels of $137 \mathrm{Cs}$ measured in surface soil from the ranchland of Mr. R. Gudgel, in surface soll collected at ranchlands located approximately 5 miles $(11 \mathrm{~km})$ from Rancho Seco on offferent compass headings from the plant, and in surface sold from the Marclel ranch located $1 \mathrm{~km}$ from the plant. Concentrations in the surface 4-cm-deep layer ranged from 0.06 to $1.65 \mathrm{pCi} / \mathrm{g}$. No $134 \mathrm{Cs}$ was detected in 
these soil samples. The concentrations are within the range of global-fallout background levels that have been reported previously (12) in soi is from the region. No ${ }^{37} \mathrm{Cs}$ or $134 \mathrm{Cs}$ originating from Rancho Seco, either as atmospheric particles or in solution from the aqueous releases, has contaminated the soil collection sites described in Tables 1,2 , and 3 of Appendix VIII.

Concentrations of radionuclides in soil-profile samples collected in August 1986 from stations RSP-1 and RSP-5 are shown in Appendix VIII (Table VIII-4). Soil from these locations had been sampled in November 1984 and analyzed (5). Station RSP-1 ts on land $50 \mathrm{~m}$ south of the irrigation pond (Station RS-17), at the western boundary line of the Rancho Seco property. RSP-5 is located $200 \mathrm{~m}$ west, or downstream, of RSP-1, $50 \mathrm{~m}$ from the south bank of the creek. This region of pastureland has not been cultivated for several years and is regularly irrigated with Clay Creek water. At RSP-5 and RSP-1, a pit was excavated next to the location sampled in 1984. Soil was sampled in increments from the side wall of the pit to a depth of $51 \mathrm{~cm}$. Table 8 is a comparison of the concentration and inventory of ${ }^{137} \mathrm{Cs}$ determined in sois samples collected in 1984 and 1986. At Station RSP-1, both the concentration and inventory in the surface 0 - to $15-\mathrm{cm}$ section of soil increased between 1984 and 1986. At Station RSP-5, the concentration at depth and the total soil column inventory of ${ }^{137} \mathrm{Cs}$ also increased, but not as much as the increase in inventory noted at station RSP-1.

While concentrations of $137 \mathrm{Cs}$ associated with environmental samples (e.g.. fish, water, sediment, and hyacinth) from the creek at RS-17 and from other downstream locations slgnificantly decreased between 1984 and 1986 , concentrations in soil sampled from irrigated ranchland have increased over the 2-y period probably as a resuit of continued irrigation.

\section{Concentrations of Radionuclide in Miscellaneous Samples}

No radioactivity was found in samples of honey from hives $0.5 \mathrm{~km}$ from the plant and the level of $137 \mathrm{Cs}$ in the flesh sample from one cow. collected in January 1986, was less than level measured in beef samples collected in 1984 and comparable to concentrations of global fallout in store purchased beef. 
Table 8. Concentrations and inventory of ${ }^{137} \mathrm{Cs}$ in soil samples collected in November 1984 and August 1986 (" (dl" means less than detection IImits).

\begin{tabular}{|c|c|c|c|c|}
\hline \multirow[b]{2}{*}{$\begin{array}{c}\text { Depth intervais } \\
\text { (cm) }\end{array}$} & \multicolumn{2}{|c|}{ November 1984} & \multicolumn{2}{|c|}{ August 1986} \\
\hline & $\begin{array}{c}137 \mathrm{Cs} \\
\text { concentration } \\
(\mathrm{pCi} / \mathrm{g})\end{array}$ & $\begin{array}{c}{ }^{137} \mathrm{Cs} \\
\text { inventory } \\
\left(\mathrm{p} C \mathrm{i} / \mathrm{cm}^{2}\right)\end{array}$ & $\begin{array}{c}137 \mathrm{Cs} \\
\text { concentration } \\
(\mathrm{pC} / \mathrm{g})\end{array}$ & $\begin{array}{c}{ }^{137 \mathrm{Cs}} \\
\text { inventory } \\
\left(\mathrm{pCi} / \mathrm{cm}^{2}\right)\end{array}$ \\
\hline \multicolumn{5}{|c|}{ Station RSP-1 } \\
\hline $0-15$ & 1.87 & $9.2^{\ddagger}$ & 2.40 & $19.3^{2}$ \\
\hline \multicolumn{5}{|c|}{ Station RSP -5} \\
\hline $0-5.1$ & 1.13 & & 1.50 & \\
\hline $5.1-10.2$ & 0.51 & & 0.87 & \\
\hline $10.2-15.2$ & 0.60 & & 0.95 & \\
\hline $15.2-20.3$ & 0.92 & & 1.19 & \\
\hline $20.3-25.4$ & 0.73 & & 0.82 & \\
\hline $25.4-30.5$ & 0.22 & & 0.08 & \\
\hline $30.5-40.5$ & $<d 1$ & & $<d 1$ & \\
\hline $40.6-50.8$ & & & $\left\langle d^{\dagger}\right.$ & \\
\hline $0-40.6$ & & $12.5^{b}$ & & $14.2^{b}$ \\
\hline
\end{tabular}

a Inventory to $15 \mathrm{~cm}$ depth.

b Inventory to $40.6 \mathrm{~cm}$ depth. 
Since mid-October 1984, the levels of ${ }^{134} \mathrm{Cs}$ and ${ }^{137} \mathrm{Cs}$, the two radionuclides contributing the major fraction of the estimated dose to individuals ( 1 ), and other gamma-emitting radionuclides discharged to Clay Creek from Rancho Seco have been significantly reduced as a result o: a liquid-effluent control program initiated by the Sacramento Municipal utility District. However, the results from our sampling program in 1986 indicate that the radionuclides previously released persist in the downstream environment and are still present in many of the aquatic dietary components, although at concentrations much lower than those measured in 1984 and 1985. The greatiy reduced activities in the aquatic environment attest to the effectiveness of the liquid-effluent control program. As in the results generated in 1984 and $1995(3,6),{ }^{134} \mathrm{Cs}$ and ${ }^{137} \mathrm{Cs}$ were the primary gammaemitting radionuclides detected in the edible flesh of different fish, crayfish, and frog legs sampled from the creek for analysis in 1986. The ${ }^{134} \mathrm{Cs}$ in aquatic samples is now approximately $25 \%$ of the ${ }^{137} \mathrm{Cs}$ concentration.

Concentrations in the flesh of fish decreased over time and with distance fron the plant outfall. These changes in concentrations can be described by exponential equations, the coefficients of which are obtained from a least squares analysis of the data. The mean concentration of $137 \mathrm{Cs}$ in fish collected from Laguna Creak below a distance of $7.5 \mathrm{~km}$ from Rancho 5 eco is now comparable to the average concentration determined in fresh-water fish randomly selected from Chicago, Illinois markets. By August 1986, the mean concentration of ${ }^{137} \mathrm{Cs}$ in the flesh of bluegill had fallen to $7 \%$ of the concentration measured in fish from comparable locations in 1984 and was 30\% of the mean concentration found in these fish during August 1985. Between March 1985 and October 1986 , the concentration of ${ }^{137} \mathrm{Cs}$ in bluegill decreased at all stations sampled; the ${ }^{137} \mathrm{Cs}$ had a mean effectlve half-life of $170 \mathrm{~d}$. The changes in the concentration of ${ }^{137} \mathrm{Cs}$ in frogs closely follow the changes in concentration measured in the flesh of bluegtil.

Concentrations in the surface $(0$ to $12 \mathrm{~cm}$ ) sections of creak sediments also declined between 1984 and 1986. Between 1985 and 1986, the mean concentration or ${ }^{137} \mathrm{Cs}$ in the surface sediments at all downstream locitions decreased resulting in an effective half-life of approximately 2 y. 
The values computed for the $137_{C 5}$ concentration factors are highest for fish from clay Creek and lowest for fish from Laguna creek. This trend is evident in the data from samples collected in 1984, 1985, and 1986. We find that stable potassium levels in the water play a role in regulating the magnitude of the ${ }^{137} \mathrm{Cs}$ concentration factor. Potassium levels in the creek water increase in a downstream direction; the higher concentrations are associated with runoff water from nearby fields.

Surface soits collected around a perimeter $11 \mathrm{~km}$ from Rancho seco and from ranchlands closer to the plant, soils not affected by the aqueous releases, showed only concentrations of ${ }^{137} \mathrm{Cs}$ originating from global fallout and no ${ }^{134} \mathrm{Cs}$. The locations sampled showed no evidence of ${ }^{137} \mathrm{Cs}$ contamination that could be perceived to originate with atmospheric particles from Rancho Seco.

Soll previously irrigated with clay Creek water retains both ${ }^{34} \mathrm{Cs}$ and $137 C_{5}$. Samples of 5011 collected near station RS-17 in 1986 contained higher inventories of $137 \mathrm{Cs}$ than was found in adjacent soli sites sampled in 1984 .

We recommend that support for the scientific activities conducted in the vicinity of Rancho Seco be extended through 1987. The studies will provide an uninterrupted record of environmental data to validate the continued effectiveness of the liquid-effluent control program. Recommendations for specific, continuing and new studies uill be proifded in a proposal for research currently in preparation.

\section{ACKNOWLEDGMENTS}

We wish to hank Mr. John Boruk and Mr. Robert Bird for assisting with sample collection and processing. This work was performed under the auspices of the U.5. Department of Energy by the Lawrence Livermore Nationa I Laboratory under contract number W-7405-ENG-48, with support from the Sacramento Municipal Utillty District under concract A0B7. 
REFERENCES

1). E.W. Bradley, Semiannual Radioactive Effluent Release Report, JanuaryJune 1986, Sacramento Municipal Utility District, Sacramento, CA. (1986).

2). R.J. Eagle, K.M. Wong, and V.E. Noshkin, Ranch Seco Liquid Effluent Pathway--Aguatic and Terrestrial Dietary Survey Report, Lawrence Livermore National Laboratory, Livermore, CA, UCID-20267 (1984).

3). V.E. Noshkin, R.J. Eagle, J.M. Dawson, J.L. Brunk, and K.M. Wong, Concentration of Radionuclides in Fresh Water Fish Downstream of Rancho Seco Nuclear Power Generating Plant, Lawrence Livermore National Laboratory, CA, UCID-20295 (1984).

4). K.M. Wong, R.J. Eagle, J.M. Dawson, J.L. Brunk, and V.E. Noshkin, Radionuclides in Sediments Collected Downstream from the Rancho Seco Nuclear Power Generating Station. Lawrence Livermore National Laboratory. Livermore, CA, UCID-20298 (1985).

5). V.E. Noshkin, K.M. Wong, R.J. Eagle, J.W. Dawson, J.L. Brunk, T.A. Jokela, Environmental Radiological Studies Downstream from Rancho Seco Nuclear Power Generating Station. Lawrence Livermore National Laboratory, Ljvermore, CA, UCID-20367 (1985).

6). V.E. Noshkin, K.M. Wong, R.J. Eagle, J.L. Brunk, T.A. Jokela, Environmental Radiological Studies Downstream from the Rancho Seco Nuclear Fower Generating Station - 1985, Lawrence Livermore National Laboratory. Livermore, CA, UCID-20641 Part I (1986).

7). V.E. Noshkin, K.M. Wong, R.J. Eagle, J.L. Brunk, T.A. Jokela, Environmental Radiological Studies Downstream from the Rancho Seco Nuclear Power Generating Station - 1985. Lawrence Livermore National Laboratory, Livermore, CA, UCIO-20641 Part II (1986). 
8). R. Gunnik and J.B. Niday, Computer Quantitative Analysis by Gamma-Ray Spectrometry: Description of the Geieral Program, Lawrence LIvermore National Laboratory, Livermore, CA, UCRL-51061, Vol. 2, (1972).

9). 3.0. Karthunen, Cesium-137 in Various Chicago Foods Environmental Measurement Laboratory, New York, NY, EML-412, III-3 (1982).

10). C.L. Feimster, An Aerial Radiological Survey of the Creeks and Tributaries near the Rancho Seco Nuclear Generating Station, Remote Sensing Laboratory, Las Vegas, N, Report No. EGG-10282-1086, UC-1 (1986).

11). H.A. Vanderploeg. D.C. Parzyak, W.H. Wi lcox, J.R. Kercher, and S.V. Kaye, Bioaccumblation Factors for Radionuclides in Freshwater Biota. Oak Ridge National Laboratory, Oak Ridge. TN, ONNL-5002 (1975).

12). C.W. Mllier, W.D. Cottrel1, J.M. Loar, J.P. Witherspoon, Evaluations of Radioactive Liquid Effluent Releases from the Rancho Seco Nuclear Power Unit, Oak Ridge National Laboratory, Oak Ridge, TN, NUREG/CR-4286, ORHL-6183 (3985). 